\title{
TUBERCULOSIS IN POLAND IN 2018
}

\author{
GRUŹLICA W POLSCE W 2018 roku
}

\author{
National Tuberculosis and Lung Diseases Research Institute \\ Department of Tuberculosis Epidemiology and Surveillance \\ Instytut Gruźlicy i Chorób Płuc \\ Zakład Epidemiologii i Organizacji Walki z Gruźlicą
}

\begin{abstract}
AIM OF THE STUDY. To evaluate the main features of tuberculosis (TB) epidemiology in 2018 in Poland and to compare with the situation in the EU/EEA countries.

METHODS. Analysis of case- based data on TB patients from National TB Register, data on anti-TB drug susceptibility testing results in cases notified in 2018, data from National Institute of Public Health- National Institute of Hygiene on HIV-positive subjects for whom TB was an AIDS-defining disease, data from Central Statistical Office on deaths from tuberculosis based on death certificates, data from the report „European Centre for Disease Prevention and Control/WHO Regional Office for Europe. Tuberculosis surveillance and monitoring in Europe 2020 - 2018 data. Stockholm: European Centre for Disease Prevention and Control, 2020". RESULTS. In 2018, 5487 TB cases were reported in Poland. The incidence rate was 14.3 cases per 100000, with large variability between voivodeships from 7.3 to 23.4 per 100000 . The mean annual decrease of TB incidence in 2014- 2018 was 3.8\%. In 2018, 4852 cases were newly diagnosed with no history of previous treatment i.e. 12.6 per 100000.635 cases i.e. 1.7 per $100000-11.6 \%$ of all registered subjects were previously treated for tuberculosis. In 2018, the number of all pulmonary tuberculosis cases was 5224 i.e. 13.7 per 100000 . Pulmonary cases represented $95.2 \%$ of all TB cases. In 2018, 243 extrapulmonary TB cases were found i.e. 0.6 per 100 000 . In the whole country there were 52 pediatric cases of tuberculosis. TB in children represented $0.9 \%$ of all cases notified in Poland in 2018. The incidence rates of tuberculosis were growing along with the age group from 0.9 per 100000 among children to 24.7 per 100000 among subjects in the age group 45-64 years (the highest incidence rate). In 2018, the incidence rate in the age group $\geq 65$ years was 21.3 per 100000 . The TB incidence among men i.e. 21.0 per 100000 was 2.6 times higher than among women i.e. 8.0 per 100000 . The biggest difference in the TB incidence between the two sex groups occurred in persons aged 55 to 59 years 44.9 vs. 9.8 and in age group 60- 64 years $-43.7 v s$. 10.2. The TB incidence in rural population was lower than in urban, respectively 13.4 per 100000 and 14.9 per 100000 . The number of all registered culture positive TB cases was 4075 . Pulmonary tuberculosis was bacteriologically confirmed in 3935 subjects. Cases confirmed by culture represented $74.3 \%$ of all TB cases and $75.3 \%$ of all pulmonary TB cases. The number of smear-positive pulmonary TB cases reported in 2018 was 2324 i.e. 6.1 per 100000 accounting for $44.3 \%$ of all pulmonary TB cases and $59.1 \%$ of pulmonary TB cases confirmed by culture. In all patients with tuberculosis in Poland in 2018 there were 48 cases with MDR-TB (among them 14 foreigners) and 83 patients with resistance to isoniazid only, representing respectively $1.3 \%$ and $2.2 \%$ of cases with known DST results (DSTs were available in $90.7 \%$ of all culture-confirmed TB cases). In 2018, there were 97 patients of foreign origin among all cases of tuberculosis in Poland. TB was AIDS-indicative disease in 14 subjects with HIV co-infection. There were 490 deaths due to tuberculosis reported in $2017-1.3$ per $100000 ; 468$ people died from pulmonary and 22 from extrapulmonary tuberculosis. Mortality among males -2.1 per 100000 - was $3.6 \mathrm{X}$ higher than among females $-0.5 .40 .2 \%$ of all TB deaths were cases 65 years old and older - 3.1 per 100 000. In 2017, there was no death from tuberculosis in children and no deaths in adolescents. In 2017, tuberculosis represented $0.1 \%$ of total mortality in Poland and $25.4 \%$ of mortality from infectious and parasitic diseases.
\end{abstract}

Orcid: 0000-0001-7693-9012; This work was carried out within the framework of the statutory activities of the National Tuberculosis and Lung Diseases Research Institute, Theme 2, Research Task No. 4 / Praca została zrealizowana w ramach działalności statutowej Instytutu Gruźlicy i Chorób Płuc, Temat 2, Zadanie Badawcze Nr 2.4.

(C) National Institute of Public Health - National Institute of Hygiene / Narodowy Instytut Zdrowia Publicznego - Państwowy Zakład Higieny 
CONCLUSIONS. In 2018, the incidence of tuberculosis in Poland was lower than in 2017. Despite a continuous decline it is still higher than the average in the EU/EEA countries. The highest incidence rates were observed in older age groups. The participation of pediatric cases is smaller than average in the EU/EEA countries. The incidence in males was more than 2 times higher than in females. The impact of migration on the characteristics of tuberculosis in Poland is not substantial. In Poland, MDR-TB is less common than the average in the EU/EEA countries.

Key words: tuberculosis (TB), TB cases, TB incidence, new cases, previously treated cases, pulmonary TB, extrapulmonary TB, TB confirmed by culture, drug susceptibility reporting, multi-drug resistant TB (MDR-TB), $T B$ in children and adolescents, TB cases of foreign origin, TB/HIV co-infection, TB in prisons, TB mortality, Poland, the National Tuberculosis Register, 2018

\section{STRESZCZENIE}

CEL PRACY. Analiza sytuacji epidemiologicznej gruźlicy w Polsce w 2018 roku przez porównanie z sytuacją w tym przedmiocie w krajach Unii Europejskiej (UE) i Europejskiego Obszaru Gospodarczego (EOG).

MATERIAL I METODY. Analiza danych zebranych w Krajowym Rejestrze Zachorowań na Gruźlicę (Rejestr) dotyczących przypadków zarejestrowanych w 2018 roku, wyników lekowrażliwości prątków z rejestrów laboratoryjnych, danych Głównego Urzędu Statystycznego o zgonach z przyczyny gruźlicy, danych Narodowego Instytutu Zdrowia Publicznego- Państwowego Zakładu Higieny o przypadkach gruźlicy jako choroby wskaźnikowej AIDS oraz raportu Europejskiego Centrum do Spraw Zapobiegania i Kontroli Chorób (ang. European Centre for Disease Prevention and Control-ECDC) o gruźlicy w krajach UE/EOG w 2018 roku.

WYNIKI. W 2018 roku zarejestrowano w Polsce 5487 przypadków gruźlicy, 300 zachorowań mniej niż w roku 2017. Zapadalność na gruźlicę wszystkich postaci wynosiła 14,3 (w roku 2017- 15,1). Największe współczynniki zapadalności na gruźlicę wszystkich postaci zarejestrowano w województwie lubelskim - 23,4; śląskim - 18,6 i mazowieckim - 17,7; najmniejszy- w województwie podlaskim - 7,3. W 11 województwach doszło do spadku zapadalności na gruźlicę w porównaniu z rokiem 2017. 88,4\% wszystkich przypadków stanowiły nowe zachorowania (4852 chorych, współczynnik 12,6). Kolejne zachorowania stanowiły 11,6\% wszystkich przypadków. 5224 osoby $(95,2 \%$ ogółu) miały gruźlicę płuc - współczynnik 13,7. Chorzy wyłącznie na gruźlicę pozapłucną w liczbie 243, stanowili 4,4\% wszystkich zachorowań. Najczęstszą postacią gruźlicy pozapłucnej było gruźlicze zapalenie opłucnej (89 zachorowań). U 11 chorych, wśród których było dwoje dzieci w wieku do 14 lat, rozpoznano gruźlicze zapalenie opon mózgowo-rdzeniowych i mózgu. W 3935 przypadkach gruźlicy płuc (75,3\%) rozpoznanie choroby było potwierdzone bakteriologicznie (współczynnik zapadalności- 10,2). Chorzy na gruźlicę płuc, w liczbie 2 324, u których prątki stwierdzono także w bakterioskopii, stanowili 44,3\% wszystkich przypadków gruźlicy płuc. 48 chorych (1,3\% przypadków ze znanymi wynikami lekowrażliwości), w tym 14 cudzoziemców, miało gruźlicę wielolekooporną (ang. multidrug-resistant tuberculosis-MDR-TB). Współczynniki zapadalności na gruźlicę rosły w kolejnych grupach wieku, ale tylko do wieku 45-64 lata. Zapadalność u osób w wieku 65 lat i starszych -21,3- była mniejsza niż w wieku od 45 do 64 lat (24,7). Zgłoszono 52 zachorowania na gruźlicę u dzieci do 14 roku życia ( $0,9 \%$ ogółu chorych) i 60 przypadków gruźlicy u młodzieży w wieku od 15 do 19 lat - współczynniki odpowiednio 0,9 i 3,3. Liczba przypadków i zapadalność w grupie nastolatków były najmniejsze w historii Rejestru. W znaczącym odsetku młodocianych chorych (90,0\%- 54 osoby) gruźlica została potwierdzona bakteriologicznie; u dzieci odsetek chorych z pewnym rozpoznaniem gruźlicy wynosił 40,4\% (21 chorych). 66 nastolatków i 2 dzieci chorych na gruźlicę płuc miało dodatnie także wyniki bakterioskopii plwociny. Jak w latach wcześniejszych, zapadalność na gruźlicę u mężczyzn była ponad dwukrotnie większa niż u kobiet. Zarejestrowano 3900 zachorowań u mężczyzn - współczynnik zapadalności 21,0 i 1587 zachorowań u kobiet - współczynnik 8,0. Największa różnica zapadalności między mężczyznami i kobietami występowała u osób w wieku od 55 do 59 lat $(44,9$ vs. 9,8) i od 60 do 64 lat $(43,7$ vs. 10,2). Cudzoziemcy (97) stanowili 1,8\% ogółu chorych. Gruźlica była chorobą wskaźnikową u 14 chorych na HIV/AIDS. Areszty śledcze i zakłady karne zgłosiły w 2018 roku 171 przypadków gruźlicy wykrytej u osób tam osadzonych (współczynnik zapadalności 230,8 na 100000 osadzonych). W 2017 roku gruźlica była przyczyną zgonu 490 osób. Współczynnik umieralności - 1,3 - był mniejszy niż w roku poprzednim $(1,4)$. Największy współczynnik umieralności z powodu gruźlicy stwierdzono w grupie wieku $\geq 65$ lat $-3,1$. Nie było zgonu z powodu gruźlicy u dzieci i młodzieży. Liczba zgonów z powodu gruźlicy u mężczyzn była 3,6 razy większa niż u kobiet. WNIOSKI. Zapadalność na gruźlicę w Polsce w 2018 roku była mniejsza niż w roku poprzednim. Utrzymują się różnice zapadalności między województwami. Odsetek przypadków gruźlicy z potwierdzeniem bakterio- 
logicznym przekroczył 75\%, co wskazuje, że tylko $25 \%$ chorych, mniej niż w krajach UE/EOG, ma jedynie kliniczne rozpoznanie gruźlicy. Największe współczynniki zapadalności stwierdza się w Polsce w starszych grupach wieku. Odsetek dzieci wśród ogółu chorych na gruźlicę wynosił 0,9\%, mniej niż średni w krajach UE/EOG (3,4\%). Zapadalność na gruźlicę u mężczyzn jest w Polsce ponad dwukrotnie większa niż u kobiet, u chorych w wieku od 55 do 64 lat ponad czterokrotnie większa. Umieralność z powodu gruźlicy była niższa niż w latach poprzednich. Zapadalność i umieralność na gruźlicę w Polsce są wciąż większe niż średnie w krajach UE/EOG. Zjawiskiem korzystnym jest natomiast mniejszy niż przeciętny w UE/EOG odsetek zachorowań na MDR-TB. W porównaniu z wieloma krajami europejskimi odsetek cudzoziemców wśród chorych na gruźlicę jest w Polsce mały.

Słowa kluczowe: gruźlica, przypadki, zapadalność, nowe zachorowania, przypadki leczone w przeszłości, gruźlica płuc, gruźlica pozapłucna, potwierdzenie bakteriologiczne gruźlicy, wyniki lekowrażliwości, gruźlica wielolekooporna (MDR-TB), gruźlica u dzieci i młodzieży, gruźlica u cudzoziemców, gruźlica u więźniów, wspólwystępowanie gruźlicy i zakażenia HIV, umieralność, Polska, Krajowy Rejestr Zachorowań na Gruźlicę, rok 2018

\section{INTRODUCTION}

Tuberculosis is an infectious disease caused by a group of Mycobacterium species called the Mycobacterium tuberculosis complex. In 2018, the World Health Organization estimated that 10 million people became newly sick with TB in the whole world. The global average TB incidence was 132 per 100000 population but the burden of diseases varied very much among countries from less than 5 to more than 500 new cases per 100000 population. Global tuberculosis incidence is estimated to be slowly declining by $1.6 \%$ per year. In many settings, multidrug-resistant TB continues to be the great threat to public health. MDR-TB is common notably in countries that were formerly republics of the Soviet Union $(1,2)$.

The prevention and control of tuberculosis in Poland is regulated by the law (the Act on the prevention and control of infections and infectious diseases in humans of 5 December 2008)(3). According to the Act, people with tuberculosis are subjected to compulsory hospitalization during the period of infectivity or because of a justified suspicion of infectivity. Treatment of tuberculosis is compulsory. The Act contains rules on reporting and registering cases of infectious disease. Physicians and feldshers who suspect or diagnose infection, infectious disease or death due to infection or infectious disease are obliged to report this fact without delay, not later than within 24 hours, to the poviat state sanitary inspector or the border state sanitary inspector responsible for the area where such diagnosis was made or to voivodship state sanitary inspector or other bodies competent with respect to type of infectious disease, infection, or death due to infectious disease. All case report forms with data on the particular case of tuberculosis are subsequently forwarded to the National Tuberculosis and Lung Diseases Research

\section{WSTĘP}

W 2018 roku na świecie na gruźlicę zachorowało 10,0 mln osób (od 9,0 do 11,0 mln). Zapadalność na gruźlicę wyniosła 132 zachorowania na 100000 ludności (od 118 do 146). Gruźlica pozostaje najczęstszą przyczyną zgonów na świecie wywołanych przez pojedynczy czynnik zakaźny, ale liczba zgonów na gruźlicę maleje. W 2018 roku zmarło z jej powodu 1,2 mln chorych, którzy nie byli zakażeni HIV (ang. human immunodeficiency virus); w 2000 roku- 27\% więcej. Średnia umieralność na gruźlicę wynosiła w 2018 roku 16 na 100000 ludności. W wielu krajach uprzemysłowionych była niższa niż 1 zgon na 100000 ludności, w niektórych krajach Afryki przekraczała 40 zgonów na 100000 ludności.

1,7 mld osób, także zgodnie z szacunkami Światowej Organizacji Zdrowia (ang. World Health Organization- WHO), jest zakażonych prątkiem gruźlicy i 5-10\% takich osób może w jakimś momencie życia zachorować na gruźlicę. Największe ryzyko zachorowania występuje u osób zakażonych HIV. Cukrzyca, niedożywienie, palenie papierosów i nadużywanie alkoholu także zwiększają, choć w znacznie mniejszym stopniu niż HIV, prawdopodobieństwo reaktywacji gruźlicy. Powszechność występowania wymienionych wyżej czynników ryzyka ma wpływ na globalną sytuację epidemiologiczną gruźlicy.

Skuteczne leczenie gruźlicy utrudnia rozpowszechnienie gruźlicy wywołanej przez prątki oporne na najsilniejsze leki przeciwprątkowe- na ryfampicynę (RR -TB) i na ryfampicynę łącznie z izoniazydem (MDR -TB). Liczbę chorych na RR-TB i MDR-TB oszacowano w 2018 roku na blisko pół miliona. Największe odsetki chorych na RR-TB i MDR-TB wśród ogółu chorych na gruźlicę stwierdza się od lat w krajach, które w przeszłości były republikami Związku Radzieckiego. Część takich chorych ma gruźlicę wielolekooporną z rozszerzoną opornością (ang. extensively drug- resistant tuberculosis - XDR-TB), ze znacznie mniejszą szansą na 
Institute. The Institute, that was designated by Chief Sanitary Inspectorate as the body competent in the field of tuberculosis, keeps the National Tuberculosis Register (Register).

The data stored in the Register are used in the health policy carried out in Poland and also are a valuable scientific database, which has been maintained in the National Tuberculosis and Lung Diseases Research Institute uninterruptedly and comprehensively since 1957.

\section{AIM OF THE STUDY}

To assess the epidemiological situation of tuberculosis in Poland in 2018 by comparison with that in the countries of the European Union (EU) and European Economic Area (EEA) taking into consideration the following parameters:

- the TB incidence in several population groups (in various age groups, in males and females),

- the proportion of extrapulmonary TB among all TB cases,

- the participation of newly diagnosed and previously treated cases among all TB cases,

- the participation of cases with bacteriological confirmation among all TB cases,

- the burden of MDR-TB,

- TB cases of foreign-origin,

- extent of the TB/HIV co-infection,

- TB incidence in prisons,

- mortality from tuberculosis. wyleczenie. Na Białorusi chorzy na MDR-TB stanowili w 2018 roku 46,0\% przypadków ze znanymi wynikami lekowrażliwości, z czego 18,8\% miało XDR-TB (1).

Sytuacja epidemiologiczna grúlicy w krajach UE/ EOG różni się znacząco, mimo napływu osób z krajów o dużym rozpowszechnieniu gruźlicy, od sytuacji globalnej. W 23 krajach Europy współczynniki zapadalności na gruźlicę były mniejsze niż 10 na 100000 (2).

W Polsce działania związane $\mathrm{z}$ zapobieganiem i zwalczaniem chorób zakaźnych, w tym gruźlicy, są uregulowane prawnie. Ustawa $\mathrm{z}$ dnia 5 grudnia 2008 r., określająca zasady i tryb zapobiegania oraz zwalczania zakażeń i chorób zakaźnych u ludzi (Dz.U. z 2019 r. poz. 1239)(3) nakłada na lekarzy i felczerów obowiązek zgłaszania zachorowań na gruźlicę. Przypadki zgłaszane są państwowemu powiatowemu inspektorowi sanitarnemu lub państwowemu granicznemu inspektorowi sanitarnemu, właściwemu dla miejsca rozpoznania lub państwowemu wojewódzkiemu inspektorowi sanitarnemu lub innym podmiotom właściwym ze względu na rodzaj choroby zakaźnej, zakażenia lub zgonu z powodu choroby zakaźnej. Wszystkie formularze zgłoszenia przypadku gruźlicy w Polsce trafiają na koniec do Instytutu Gruźlicy i Chorób Płuc, gdzie od 1957 roku prowadzony jest w sposób ciągły Krajowy Rejestr Zachorowań na Gruźlicę.

Rejestr służy celom nadzoru nad gruźlicą i stanowi bazę naukową, umożliwiającą analizy sytuacji epidemiologicznej gruźlicy w Polsce i wieloletnich trendów wskaźników dotyczących choroby.

Instytut Gruźlicy i Chorób Płuc przekazuje dane o gruźlicy w Polsce do ECDC oraz do WHO.

\section{CEL PRACY}

Celem pracy jest ocena sytuacji epidemiologicznej gruźlicy w Polsce w 2018 roku uwzględniająca:

- zapadalność w grupach wieku i płci,

- udział wśród ogółu przypadków gruźlicy w 2018 roku:

- nowych zachorowań i wznów,

- gruźlicy płuc i pozapłucnej,

- gruźlicy z potwierdzeniem bakteriologicznym i gruźlicy płuc $z$ dodatnimi wynikiem badania bakterioskopowego plwociny

- zachorowań wywołanych przez prątki oporne na izoniazyd i MDR-TB

- zachorowań u cudzoziemców

- przypadków gruźlicy w więzieniach,

- współwystępowanie gruźlicy i zakażenia HIV,

- umieralność z powodu gruźlicy i

- porównanie sytuacji epidemiologicznej gruźlicy w Polsce z sytuacją w krajach UE i EOG. 


\section{MATERIAL AND METHODS}

Analysis of the data on TB cases reported in 2018 to the Register, on anti-TB drug susceptibility testing results (DST), on deaths from TB in 2017 (data obtained from the Central Statistical Office), on subjects with HIV co-infection in whom tuberculosis was the AIDS- defining disease (data provided by the National Institute of Public Health-National Institute of Hygiene) and analysis of the data from the report of the European Centre for Disease Prevention and Control (ECDC)/WHO Regional Office for Europe. Tuberculosis surveillance and monitoring in Europe 2020-2018 data. Stockholm: European Centre for Disease Prevention and Control, 2020.

TB drug susceptibility results were from all the laboratories in the country that performed such tests.

\section{RESULTS}

In 2018, 5487 cases of tuberculosis were reported in Poland meaning 300 cases less than in the year before and 2749 cases less than in 2009. In 2018, the incidence rate of all forms of tuberculosis was 14.3 per 100000 population (later in the text, the denominator in rates is skipped) and was lower by $5.3 \%$ as compared with 2017 (15.1) and 33.8\% less than ten years previously (21.6 in 2009)(Tab. I).

In 2018, as in previous years, considerable differences in the incidence of tuberculosis between the voivodships were observed. For years, the very same voivodships have been among those with the lowest or the highest incidence rates. The highest incidence of tuberculosis was in the voivodship lubelskie - rate 23.4; śląskie - 18.6; mazowieckie - 17.7. The lowest incidence of tuberculosis in the country was in voivodship podlaskie - 7.3; wielkopolskie -8.0 and warmińsko-mazurskie -8.7 . In 2018, compared to the previous year, a decrease in the TB incidence of tuberculosis occurred in 11 voivodships. The incidence rates higher than in 2017 were found in 5 voivodships: pomorskie $(15.0 \mathrm{vs}$. 11.4), zachodnio-pomorskie (11.9 vs. 10.8), lubelskie (23.4 vs. 21.9$)$, podkarpackie (12.4 vs. 12.1$)$ and świętokrzyskie (16.8 vs. 16.5) (Tab. II).

In 2018,4852 persons $(88.4 \%$ of all TB cases in Poland; rate 12.6) were new TB cases. This means that they have never been treated for TB or have taken anti-TB drugs for less than one month. Previously treated cases represented $11.6 \%$ of the total notified TB cases (635 patients; rate 1.7).

In 2018, 5224 subjects $(95.2 \%$ of all TB cases) were diagnosed with pulmonary tuberculosis; rate 13.7. The most common form of pulmonary TB was infiltrative TB (94.7\% of cases). Persons with

\section{MATERIAŁ I METODY}

Analizowano następujące zbiory danych dotyczące gruźlicy:

- dane zgromadzone w Krajowym Rejestrze Zachorowań na Gruźlicę, uzyskane z formularzy zgłoszenia podejrzenia lub rozpoznania gruźlicy (ZLK-2) dotyczące przypadków zarejestrowanych w 2018 roku;

- wyniki lekowrażliwości prątków z rejestrów laboratoryjnych;

- dane uzyskane przez Główny Urząd Statystyczny o zgonach z powodu gruźlicy w 2017 roku ;

- dane Narodowego Instytutu Zdrowia PublicznegoPaństwowego Zakładu Higieny o przypadkach gruźlicy jako choroby definiującej AIDS u osób zakażonych HIV;

- raport: European Centre for Disease Prevention and Control/WHO Regional Office for Europe. Tuberculosis surveillance and monitoring in Europe 2020 - 2018 data. Stockholm: European Centre for Disease Prevention and Control, 2020.

Współczynniki zapadalności/umieralności obliczono na 100000 osób badanej populacji. W tekście nie podawano mianownika współczynników.

\section{WYNIKI}

W 2018 roku zarejestrowano 5487 zachorowań na gruźlicę, co oznacza 300 przypadków gruźlicy mniej niż w roku poprzednim i 2749 przypadków mniej w porównaniu z rokiem 2009.

Zapadalność na gruźlicę wszystkich postaci w 2018 roku wynosiła 14,3 i była mniejsza o $5,3 \% \mathrm{w}$ porównaniu z rokiem 2017 oraz o 33,8\% w porównaniu z rokiem 2009, w którym wynosiła 21,6 (Tab. I).

Znaczne różnice współczynników zapadalności na gruźlicę między województwami, obserwowane od lat, wystąpiły także w roku 2018. W 2018 roku największą zapadalność na gruźlicę wszystkich postaci zarejestrowano w województwach: lubelskim - 23,4; śląskim - 18,6; mazowieckim - 17,7. W województwach: podlaskim - 7,3; wielkopolskim - 8,0; warmińsko-mazurskim - 8,7 i kujawsko-pomorskim - 10,1 współczynniki zapadalności na gruźlicę wszystkich postaci były najmniejsze w całym kraju. W 2018 roku spadek zapadalności na gruźlicę wszystkich postaci w porównaniu $\mathrm{z}$ rokiem poprzednim wystąpił w 11 województwach. Współczynniki zapadalności większe niż w roku 2017 stwierdzono w woj. pomorskim $(15,0$ vs. 11,4); zachodnio-pomorskim $(11,9$ vs. 10,8$)$; lubelskim $(23,4$ vs. 21,9$)$; podkarpackim $(12,4$ vs. 12,1) i świętokrzyskim $(16,8$ vs. 16,5) (Tab. II).

Nowe przypadki, bez historii wcześniejszego leczenia gruźlicy - było ich w 2018 roku 4852 - współczyn- 
Table I. Tuberculosis cases and tuberculosis notification rates by age groups. Poland $1957-2018$. Rates per 100000 population. Data from National TB Register

Tabela I. Zapadalność na gruźlicę w Polsce w latach 1957 - 2018 w grupach wieku. Współczynniki na 100000 ludności. Dane z Krajowego Rejestru Zachorowań na Gruźlicę

\begin{tabular}{|c|c|c|c|c|c|c|c|c|c|c|c|c|}
\hline \multirow{2}{*}{ Years } & Total & $0-14$ & $15-19$ & $20-44$ & $45-64$ & $65+$ & Total & $0-14$ & $15-19$ & $20-44$ & $45-64$ & $65+$ \\
\hline & \multicolumn{6}{|c|}{ Number of cases in age groups } & \multicolumn{6}{|c|}{ Rates per 100000 population } \\
\hline 1957 & 82201 & 16402 & 5757 & 37141 & 19255 & 3646 & 290.4 & 181.0 & 266.1 & 370.6 & 351.6 & 230.1 \\
\hline 1960 & 85529 & 16580 & 4781 & 37244 & 22746 & 4178 & 289.3 & 167.6 & 245.2 & 365.7 & 390.3 & 244.9 \\
\hline 1965 & 57511 & 4553 & 3879 & 23914 & 18520 & 6645 & 182.6 & 46.6 & 134.1 & 221.6 & 314.5 & 309.6 \\
\hline 1970 & 42142 & 1273 & 2861 & 18440 & 13001 & 6567 & 128.5 & 14.3 & 83.1 & 158.3 & 209.6 & 242.0 \\
\hline 1975 & 26255 & 535 & 1695 & 11844 & 7753 & 4428 & 77.2 & 6.5 & 49.5 & 94.8 & 116.0 & 136.5 \\
\hline 1980 & 25807 & 573 & 990 & 11358 & 8434 & 4452 & 72.5 & 6.6 & 35.7 & 84.7 & 117.9 & 123.8 \\
\hline 1985 & 21650 & 314 & 621 & 9226 & 7678 & 3811 & 58.2 & 3.3 & 24.7 & 66.3 & 98.7 & 108.8 \\
\hline 1990 & 16136 & 225 & 421 & 6682 & 5818 & 2990 & 42.3 & 2.3 & 14.8 & 46.6 & 77.3 & 78.0 \\
\hline 2000 & 11477 & 103 & 241 & 3978 & 4221 & 2934 & 29.7 & 1.4 & 7.2 & 28.0 & 47.2 & 62.4 \\
\hline 2001 & 10672 & 124 & 199 & 3600 & 4052 & 2697 & 27.6 & 1.7 & 6.0 & 25.4 & 44.2 & 56.3 \\
\hline 2002 & 10475 & 125 & 211 & 3203 & 4175 & 2761 & 27.4 & 1.8 & 6.4 & 23.1 & 44.8 & 56.8 \\
\hline 2003 & 10124 & 100 & 184 & 3045 & 3968 & 2827 & 26.5 & 1.5 & 5.8 & 21.9 & 41.7 & 57.6 \\
\hline 2004 & 9493 & 120 & 129 & 2836 & 3835 & 2573 & 24.9 & 1.9 & 4.2 & 20.3 & 39.5 & 51.7 \\
\hline 2005 & 9269 & 99 & 156 & 2717 & 3760 & 2537 & 24.3 & 1.6 & 5.3 & 19.4 & 38.0 & 50.9 \\
\hline 2006 & 8587 & 69 & 156 & 2529 & 3655 & 2178 & 22.5 & 1.1 & 5.5 & 18.0 & 36.4 & 42.8 \\
\hline 2007 & 8614 & 74 & 135 & 2538 & 3762 & 2105 & 22.6 & 1.2 & 4.9 & 18.0 & 37.0 & 41.1 \\
\hline 2008 & 8081 & 76 & 115 & 2248 & 3685 & 1957 & 21.2 & 1.3 & 4.3 & 15.9 & 35.8 & 38.1 \\
\hline 2009 & 8236 & 99 & 131 & 2250 & 3704 & 2052 & 21.6 & 1.7 & 5.1 & 15.8 & 35.6 & 39.9 \\
\hline 2010 & 7509 & 62 & 114 & 2086 & 3441 & 1806 & 19.7 & 1.1 & 4.6 & 14.6 & 32.8 & 34.9 \\
\hline 2011 & 8478 & 111 & 130 & 2171 & 3895 & 2171 & 22.2 & 1.9 & 5.4 & 15.2 & 37.0 & 41.9 \\
\hline 2012 & 7542 & 95 & 166 & 1996 & 3404 & 1881 & 19.6 & 1.6 & 7.3 & 13.8 & 32.1 & 34.8 \\
\hline 2013 & 7250 & 116 & 113 & 1903 & 3241 & 1877 & 18.8 & 2.0 & 5.2 & 13.2 & 30.8 & 33.7 \\
\hline 2014 & 6698 & 70 & 86 & 1787 & 3001 & 1754 & 17.4 & 1.2 & 4.1 & 12.4 & 28.7 & 30.4 \\
\hline 2015 & 6430 & 81 & 83 & 1752 & 2909 & 1605 & 16.7 & 1.4 & 4.1 & 12.2 & 28.1 & 26.9 \\
\hline 2016 & 6444 & 103 & 76 & 1801 & 2853 & 1611 & $\begin{array}{ll}16.8 \\
\end{array}$ & 1.8 & 3.9 & 12.6 & 27.8 & 26.0 \\
\hline 2017 & 5787 & 68 & 69 & 1604 & 2601 & 1445 & 15.1 & 1.2 & 3.6 & 11.3 & 25.6 & 22.6 \\
\hline 2018 & 5487 & 52 & 60 & 1473 & 2494 & 1408 & 14.3 & 0.9 & 3.3 & 10.5 & 24.7 & 21.3 \\
\hline
\end{tabular}

diagnosis of caseous pneumonia and miliary $\mathrm{TB}$ represented $0.2 \%$ of all TB cases, with fibrouscavernous tuberculosis- $0.2 \%$. It is lower than ten years ago not to mention the more distant past. In 2009 the proportion of cases of caseous pneumonia and miliary TB was $1.0 \%$; of fibrous-cavernous tuberculosis $-0.9 \%$.

In 2018, only extrapulmonary tuberculosis (without lesions in the lungs) was diagnosed in 243 patients ( $4.4 \%$ of all registered cases - rate 0.6$)$. Most of these patients had pleural TB (89 cases), following in the number of patients was peripheral lymph node TB (36 cases), bone and joint TB (32 cases, including 14 with spinal manifestation) and urogenital TB (32 cases). Eleven subjects, two children among them, were diagnosed with tuberculous meningitis or with other central nervous system localization of TB. Of nik 12,6 - stanowiły 88,4\% ogółu zachorowań. Ponowne zachorowania - w liczbie 635 - współczynnik 1,7 stanowiły $11,6 \%$ wszystkich zgłoszonych przypadków.

Najczęstszą postacią gruźlicy była gruźlica płuc, która stanowiła w 2018 roku 95,2\% wszystkich zachorowań. Zarejestrowano 5224 przypadki gruźlicy płuc - współczynnik 13,7. W 23 przypadkach gruźlica płuc występowała razem z gruźlicą pozapłucną. Chorzy z jednoczesnym procesem gruźliczym w płucach i w innych narządach są rejestrowani jako przypadki gruźlicy płuc. Chorzy tylko na gruźlicę pozapłucną 243 przypadki - współczynnik 0,6 stanowili 4,4\% ogółu chorych zarejestrowanych w 2018 roku. Podobnie jak w latach wcześniejszych, najczęstszą postacią gruźlicy pozapłucnej było gruźlicze zapalenie opłucnej - 89 zachorowań - 36,6\% wszystkich przypadków o lokalizacji pozapłucnej. Na drugim miejscu była gruźlica 
Table II. Tuberculosis cases and tuberculosis notification rates by voivodships. Poland 2014-2018. Rates per 100000 population. Data from National TB Register

Tabela II. Zapadalność na gruźlicę w Polsce wg województw w latach 2014-2018. Współczynniki na 100000 ludności. Dane z Krajowego Rejestru Zachorowań na Gruźlicę

\begin{tabular}{|l|c|c|c|c|c|c|c|c|c|c|}
\hline \multirow{2}{*}{ Voivodships } & \multicolumn{9}{|c}{ Numbers } & \multicolumn{5}{c|}{ Rates } \\
\cline { 2 - 11 } & 2014 & 2015 & 2016 & 2017 & 2018 & 2014 & 2015 & 2016 & 2017 & 2018 \\
\hline Poland & 6698 & 6430 & 6444 & 5787 & 5487 & 17.4 & 16.7 & 16.8 & 15.1 & 14.3 \\
\hline Dolnośląskie & 547 & 484 & 435 & 427 & 377 & 18.8 & 16.7 & 15.0 & 14.7 & 13.0 \\
\hline Kujawsko-pomorskie & 287 & 297 & 279 & 239 & 211 & 13.7 & 14.2 & 13.4 & 11.5 & 10.1 \\
\hline Lubelskie & 570 & 486 & 444 & 466 & 497 & 26.5 & 22.7 & 20.8 & 21.9 & 23.4 \\
\hline Lubuskie & 143 & 115 & 130 & 131 & 119 & 14.0 & 11.3 & 12.8 & 12.9 & 11.7 \\
\hline Lódzkie & 572 & 554 & 518 & 456 & 406 & 22.8 & 22.2 & 20.8 & 18.4 & 16.4 \\
\hline Małopolskie & 538 & 555 & 497 & 458 & 440 & 16.0 & 16.5 & 14.7 & 13.5 & 13.0 \\
\hline Mazowieckie & 973 & 794 & 1304 & 1038 & 954 & 18.3 & 14.9 & 24.3 & 19.3 & 17.7 \\
\hline Opolskie & 132 & 165 & 154 & 133 & 127 & 13.2 & 16.5 & 15.5 & 13.4 & 12.9 \\
\hline Podkarpackie & 336 & 348 & 326 & 257 & 263 & 15.8 & 16.4 & 15.3 & 12.1 & 12.4 \\
\hline Podlaskie & 134 & 125 & 121 & 131 & 86 & 11.2 & 10.5 & 10.2 & 11.1 & 7.3 \\
\hline Pomorskie & 330 & 361 & 332 & 265 & 349 & 14.4 & 15.7 & 14.4 & 11.4 & 15.0 \\
\hline Śląskie & 1154 & 1213 & 972 & 952 & 844 & 25.1 & 26.5 & 21.3 & 20.9 & 18.6 \\
\hline Świętokrzyskie & 296 & 277 & 289 & 206 & 209 & 23.4 & 22.0 & 23.0 & 16.5 & 16.8 \\
\hline Warmińsko-mazurskie & 166 & 132 & 152 & 132 & 124 & 11.5 & 9.2 & 10.6 & 9.2 & 8.7 \\
\hline Wielkopolskie & 321 & 289 & 281 & 311 & 279 & 9.3 & 8.3 & 8.1 & 8.9 & 8.0 \\
\hline Zachodnio-pomorskie & 199 & 235 & 210 & 185 & 202 & 11.6 & 13.7 & 12.3 & 10.8 & 11.9 \\
\hline
\end{tabular}

all 5224 cases of pulmonary tuberculosis reported in 2018, 23 had also extrapulmonary TB. Such patients are registered as cases of pulmonary tuberculosis. In Poland, the extrapulmonary TB rate has been low for years.

In 2018, bacteriological (culture) confirmation of TB was obtained in 4075 patients $(74.3 \%$ of all TB cases) including 3935 cases with pulmonary TB (75.3\% of all pulmonary TB cases). Incidence rate of all bacteriologically confirmed TB was 10.6; of pulmonary tuberculosis -10.2 (Tab. III).

The highest incidence rates of bacteriologically confirmed pulmonary TB were found in voivodships: lubelskie - 14.5; mazowieckie - 12.2; świętokrzyskie - 12.1 and dolnośląskie - 11.8 while the lowest in voivodship warmińsko-mazurskie - 6.0; podlaskie 6.4 and wielkopolskie -6.7 .

In 2018, 2324 subjects in Poland had highly infectious tuberculosis, i.e. positive sputum smears; rate 6.1 (44.3\% of all patients with pulmonary tuberculosis and $59.1 \%$ of culture positive pulmonary tuberculosis) (Tab. IV). obwodowych węzłów chłonnych -36 chorych i kolejno: gruźlica kości i stawów - 32 chorych, w tym 14 przypadków gruźlicy kręgosłupa oraz gruźlica narządów moczowo-płciowych - 32 chorych. Jedenaście osób zachorowało na gruźlicze zapalenie opon mózgowo-rdzeniowych i mózgu. W roku 2018 zarejestrowano dwa zachorowania na gruźlicze zapalenie opon mózgowo-rdzeniowych i mózgu w grupie dzieci (0-14 lat).

W 2018 roku gruźlica została potwierdzona bakteriologicznie, tzn. w sposób definitywny, u 4075 chorych, w tym w 3935 przypadkach gruźlicy płuc. Zapadalność na wszystkie postaci gruźlicy potwierdzonej bakteriologicznie wynosiła 10,6; zapadalność na gruźlicę płuc potwierdzoną w posiewach - 10,2. Chorzy z potwierdzeniem bakteriologicznym stanowili 74,3\% ogółu chorych. Wśród chorych na gruźlicę płuc odsetek ten wynosił $75,3 \%$. W całej grupie 243 chorych na gruźlicę pozapłucną rozpoznanie potwierdzono bakteriologicznie u $140-57,6 \%$.

Największe w kraju współczynniki zapadalności na gruźlicę płuc potwierdzoną bakteriologicznie, czyli rozpoznaną w sposób pewny, stwierdzono w np. województwach.: lubelskim - 14,5; mazowieckim - 12,2; świętokrzyskim - 12,1 i dolnośląskim - 11,8. W województwach: warmińsko-mazurskim $-6,0$; podlaskim $-6,4$ i wielkopolskim - 6,7 zapadalność na gruźlicę potwierdzoną w posiewach była najmniejsza w kraju (Tab. III). 
Table III. Pulmonary tuberculosis confirmed by culture: cases and notification rates by age in Poland 2009-2018. Rates per 100000 population. Data from National TB Register

Tabela III. Zapadalność na gruźlicę potwierdzoną bakteriologicznie w Polsce w latach 2009-2018 w grupach wieku. Współczynniki na 100000 ludności. Dane z Krajowego Rejestru Zachorowań na Gruźlicę

\begin{tabular}{|c|c|c|c|c|c|c|c|c|c|c|c|c|}
\hline \multirow{2}{*}{ Year } & \multicolumn{9}{|c|}{ Number of cases in age groups (years) } & \multicolumn{6}{|c|}{ Rate per 100 000 population } \\
\cline { 2 - 16 } & Total & $0-14$ & $15-19$ & $20-44$ & $45-64$ & $65+$ & Total & $0-14$ & $15-19$ & $20-44$ & $45-64$ & $65+$ \\
\hline 2009 & 5035 & 13 & 77 & 1547 & 2252 & 1146 & 13.2 & 0.2 & 3.0 & 10.9 & 21.7 & 22.3 \\
\hline 2010 & 4585 & 15 & 71 & 1395 & 2098 & 1006 & 12.0 & 0.3 & 2.9 & 9.8 & 20.0 & 19.4 \\
\hline 2011 & 5327 & 19 & 70 & 1525 & 2466 & 1247 & 13.9 & 0.3 & 2.9 & 10.7 & 23.4 & 24.1 \\
\hline 2012 & 4870 & 17 & 87 & 1458 & 2246 & 1062 & 12.6 & 0.3 & 3.8 & 10.1 & 21.2 & 19.7 \\
\hline 2013 & 4663 & 13 & 56 & 1389 & 2133 & 1072 & 12.1 & 0.2 & 2.6 & 9.6 & 20.2 & 19.2 \\
\hline 2014 & 4603 & 14 & 58 & 1356 & 2073 & 1102 & 12.0 & 0.2 & 2.8 & 9.4 & 19.8 & 19.1 \\
\hline 2015 & 4472 & 12 & 41 & 1333 & 2082 & 1004 & 11.6 & 0.2 & 2.0 & 9.3 & 20.1 & 16.8 \\
\hline 2016 & 4475 & 10 & 45 & 1387 & 2039 & 994 & 11.6 & 0.2 & 2.3 & 9.7 & 19.9 & 16.1 \\
\hline 2017 & 4057 & 10 & 47 & 1221 & 1883 & 896 & 10.6 & 0.2 & 2.5 & 8.6 & 18.5 & 14.0 \\
\hline 2018 & 3935 & 14 & 52 & 1158 & 1852 & 859 & 10.2 & 0.2 & 2.8 & 8.3 & 18.3 & 13.0 \\
\hline
\end{tabular}

Table IV. Pulmonary sputum smear and culture positive cases of tuberculosis and notification rates by age groups. Poland 1995-2018. Rates per 100000 population. Data from National TB Register

Tabela IV. Zapadalność na gruźlicę płuc potwierdzoną w posiewie, z dodatnim wynikiem badania bakterioskopowego w grupach wieku. Polska w latach 1995 - 2018. Współczynniki na 100000 ludności. Dane z Krajowego Rejestru Zachorowań na Gruźlicę

\begin{tabular}{|c|c|c|c|c|c|c|c|c|c|c|c|c|}
\hline \multirow{2}{*}{ Year } & \multicolumn{6}{|c|}{ Number of cases in age groups (years) } & \multicolumn{6}{|c|}{ Rates per 100000 population } \\
\hline & Total & $0-14$ & $15-19$ & $20-44$ & $45-64$ & $65+$ & Total & $0-14$ & $15-19$ & $20-44$ & $45-64$ & $65+$ \\
\hline 1995 & 4273 & 6 & 77 & 1910 & 1453 & 827 & 11.1 & 0.1 & 2.4 & 13.3 & 18.2 & 19.4 \\
\hline 1996 & 4137 & 11 & 51 & 1807 & 1393 & 875 & 10.7 & 0.1 & 1.6 & 12.6 & 17.2 & 20.0 \\
\hline 1997 & 4054 & 10 & 60 & 1747 & 1424 & 813 & 10.5 & 0.1 & 1.8 & 12.2 & 17.1 & 18.2 \\
\hline 1999 & 3711 & 10 & 69 & 1471 & 1434 & 727 & 9.6 & 0.1 & 2.1 & 10.3 & 16.4 & 15.7 \\
\hline 2000 & 3713 & 2 & 54 & 1525 & 1321 & 811 & 9.6 & 0.0 & 1.6 & 10.7 & 14.8 & 17.3 \\
\hline 2001 & 3636 & 9 & 55 & 1442 & 1347 & 783 & 9.4 & 0.1 & 1.6 & 10.2 & 14.7 & 16.4 \\
\hline 2002 & 3432 & 6 & 58 & 1228 & 1394 & 746 & 9.0 & 0.1 & 1.8 & 8.9 & 15.0 & 15.3 \\
\hline 2003 & 3501 & 5 & 66 & 1235 & 1391 & 804 & 9.2 & 0.1 & 2.1 & 8.9 & 14.6 & 16.4 \\
\hline 2004 & 3219 & 3 & 37 & 1166 & 1355 & 658 & 8.4 & 0.0 & 1.2 & 8.4 & 13.9 & 13.9 \\
\hline 2005 & 3253 & 6 & 53 & 1115 & 1361 & 718 & 8.5 & 0.1 & 1.8 & 8.0 & 13.8 & 14.4 \\
\hline 2006 & 3307 & 2 & 44 & 1125 & 1463 & 673 & 8.7 & 0.0 & 1.6 & 8.0 & 14.6 & 11.3 \\
\hline 2007 & 3291 & 4 & 30 & 1026 & 1481 & 640 & 8.6 & 0.1 & 1.1 & 7.3 & 14.6 & 12.5 \\
\hline 2008 & 3047 & 9 & 36 & 981 & 1477 & 544 & 8.0 & 0.2 & 1.4 & 6.9 & 14.4 & 10.6 \\
\hline 2009 & 3063 & 6 & 36 & 974 & 1458 & 589 & 8.0 & 0.1 & 1.4 & 6.9 & 14.0 & 11.4 \\
\hline 2010 & 2803 & 5 & 36 & 895 & 1351 & 516 & 7.3 & 0.1 & 1.5 & 6.3 & 12.9 & 10.0 \\
\hline 2011 & 2916 & 6 & 36 & 878 & 1434 & 562 & 7.6 & 0.1 & 1.5 & 6.1 & 13.6 & 10.8 \\
\hline 2012 & 2778 & 2 & 45 & 901 & 1307 & 523 & 7.2 & 0.0 & 2.0 & 6.2 & 12.3 & 9.7 \\
\hline 2013 & 2859 & 5 & 31 & 889 & 1368 & 566 & 7.4 & 0.1 & 1.4 & 6.2 & 13.0 & 10.2 \\
\hline 2014 & 2800 & 6 & 34 & 874 & 1345 & 541 & 7.3 & 0.1 & 1.6 & 6.1 & 12.9 & 9.4 \\
\hline 2015 & 2714 & 4 & 23 & 826 & 1375 & 486 & 7.1 & 0.1 & 1.1 & 5.7 & 13.3 & 8.1 \\
\hline 2016 & 2612 & 2 & 23 & 841 & 1276 & 470 & 6.8 & 0.0 & 1.2 & 5.9 & 12.4 & 7.6 \\
\hline 2017 & 2472 & 3 & 26 & 768 & 1243 & 432 & 6.4 & 0.1 & 1.4 & 5.4 & 12.2 & 6.7 \\
\hline 2018 & 2324 & 2 & 36 & 690 & 1166 & 430 & 6.1 & 0.0 & 2.0 & 4.9 & 11.5 & 6.5 \\
\hline
\end{tabular}


In 2018, as in the previous years from 2006, the incidence rate of smear positive pulmonary tuberculosis was the highest in the age group from 45 to 64 years (11.5 in 2018). The highest incidence rates of sputum smear positive tuberculosis were reported in voivodship zachodnio-pomorskie - 8.1 and pomorskie - 8.0; the lowest - in lubuskie - 3.2.

In 2018, as earlier, there were differences between voivodships relating the proportion of TB pulmonary cases with bacteriological confirmation. The percentage of cases with bacteriological confirmation among all pulmonary cases ranged from $64.8 \%$ in voivodship lubelskie to $93.4 \%$ in voivodship kujawsko-pomorskie and dolnośląskie. The rank-list of voivodships by culture confirmed pulmonary TB notifications rates presents (Tab. V).
Chorzy na gruźlicę płuc, u których prątki stwierdzono także w bakterioskopii, stanowili 44,3\% wszystkich chorych na gruźlicę płuc i 59,1\% chorych na gruźlicę płuc z potwierdzeniem bakteriologicznym. Zarejestrowano 2324 takie przypadki - współczynnik 6,1 (Tab. IV). Największą zapadalność na gruźlicę płuc z dodatnim wynikiem bakterioskopii odnotowano w woj. zachodnio-pomorskim - współczynnik 8,1 i woj. pomorskim - współczynnik 8,0; najniższą w woj. lubuskim 3,2 . Największy odsetek chorych z dodatnim wynikiem bakterioskopii wśród ogółu chorych na gruźlicę płuc stwierdzono w woj. zachodnio-pomorskim - 70,1\%; najmniejszy w woj. łódzkim - 21,7\%.

Uwidoczniły się, jak w latach poprzednich, różnice między województwami odnośnie odsetka zachorowań na gruźlicę płuc potwierdzoną bakteriologicznie: od $64,8 \%$ w woj. lubelskim do $93,4 \%$ w woj. dolnośląskim i kujawsko-pomorskim (Tab. V).

Table V. Rank-list of voivodships by percentage of culture confirmed pulmonary tuberculosis cases in total notified pulmonary cases. Poland 2018. Data from National TB Register

Tabela V. Ranking województw wg udziału (w \% ) chorych na gruźlicę płuc potwierdzoną bakteriologicznie wśród ogółu chorych na gruźlicę płuc. Polska 2018 rok. Dane z Krajowego Rejestru Zachorowań na Gruźlicę

\begin{tabular}{|l|c|l|c|}
\hline \multicolumn{1}{|c|}{ Voivdeships } & $\%$ & \multicolumn{1}{c|}{ Rank-list } & 75.0 \\
\hline Poland & 75.0 & Poland & 93.4 \\
\hline Dolnośląskie & 93.4 & Dolnośląskie & 93.4 \\
\hline Kujawsko-pomorskie & 93.4 & Kujawsko-pomorskie & 90.5 \\
\hline Lubelskie & 64.8 & Podlaskie & 87.8 \\
\hline Lubuskie & 71.9 & Zachodnio-pomorskie & 86.6 \\
\hline Lódzkie & 66.8 & Wielkopolskie & 81.3 \\
\hline Małopolskie & 71.6 & Pomorskie & 79.5 \\
\hline Mazowieckie & 72.7 & Podkarpackie & 77.5 \\
\hline Opolskie & 77.5 & Opolskie & 73.7 \\
\hline Podkarpackie & 79.5 & Świętokrzyskie & 72.7 \\
\hline Podlaskie & 90.5 & Mazowieckie & 71.9 \\
\hline Pomorskie & 81.3 & Lubuskie & 71.6 \\
\hline Śląskie & 65.1 & Małopolskie & 71.1 \\
\hline Świętokrzyskie & 73.7 & Warmińsko-mazurskie & 66.8 \\
\hline Warmińsko-mazurskie & 71.1 & Łódzkie & 65.1 \\
\hline Wielkopolskie & 86.6 & Śląskie & 64.8 \\
\hline Zachodnio-pomorskie & 87.8 & Lubelskie & \\
\hline
\end{tabular}

Diagnosing tuberculosis on a clinical basis only, without obtaining confirmation in cultures, concern the possibility of overdiagnosis.

Extrapulmonary TB was confirmed by culture in $57.6 \%$ of 243 cases (140 patients).

In 2018, 48 patients in Poland had MDR-TB, of which 13 had extremely drug-resistant TB (XDR-TB). 14 MDR-TB cases were of foreign origin $(29.2 \%)$. Subjects with MDR-TB represented $1.3 \%$ of the cases with known drug susceptibility testing results (DST results were available in $90.7 \%$ of all TB cases with
W 2018 roku u 0,2\% chorych na gruźlicę stwierdzono gruźlicę włóknisto-jamistą; serowate zapalenie płuc i prosówkę gruźliczą rozpoznano u 0,2\% przypadków. Większość chorych, czyli 94,7\%, miała gruźlicę naciekową płuc.

W 2018 roku MDR-TB rozpoznano u 48 chorych, w tym u 14 cudzoziemców. Przypadki MDR-TB stanowiły $1,2 \%$ wszystkich zachorowań na gruźlicę potwierdzoną bakteriologicznie oraz 1,3\% zachorowań ze znanymi wynikami lekowrażliwości $(90,7 \%$ chorych z dodatnimi wynikami posiewów). Oporność na sam 
positive cultures, which according to the European Centre for Disease Prevention and Control means completeness of DST data). There were 83 patients (2.0\% of cases with known DST) with resistance of M. tuberculosis to isoniazid only.

In 2018, as in earlier years, the highest incidence rates of TB were observed in older age groups. The rates increased with age from 0.9 in children (age from 0 to 14 years) to 24.7 in subjects aged 45 64 years. In the age group 65 years and older the incidence rate was 21.3. The patients aged 45-64 years represented $45.5 \%$ of all cases and were the biggest group. The mean age of new cases of tuberculosis of Polish origin was 54.2 years. The highest incidence rates in the age group 45-64 were observed also in regards to pulmonary $\mathrm{TB}$ confirmed by culture and to pulmonary $\mathrm{TB}$ confirmed by culture but also with positive sputum smears (Tab. I, III, IV,VI). tylko izoniazyd wykryto u 83 chorych $(2,0 \%$ chorych na gruźlicę potwierdzoną bakteriologicznie i 2,2\% przypadków ze znanymi wynikami lekowrażliwości).

W 2018 roku współczynnik zapadalności na gruźlicę wzrastał w kolejnych grupach wieku, ale tylko do wieku 45-64 lata. Współczynniki wynosiły od 0,9 wśród dzieci do 14 roku życia do 24,7 u osób w wieku od 45 do 64 lat. Chorzy w wieku od 45 do 64 lat stanowili największy odsetek ogółu chorych na gruźlicę (45,5\%). W latach wcześniejszych największe współczynniki zapadalności stwierdzano w najstarszej grupie wieku, tzn. u osób $\geq 65$ lat. Od 2015r. największe współczynniki zapadalności są w grupie od 45 do 64 lat. U osób w tym wieku stwierdza się także największą zapadalność na gruźlicę płuc potwierdzoną bakteriologicznie i na gruźlicę płuc z dodatnimi wynikami bakterioskopii plwociny. W 2018 roku współczynnik zapadalności u osób w wieku 65 lat i starszych wynosił 21,3 i był mniejszy niż w grupie wieku od 45 do 64 lat (Tab. I,III,IV,VI).

Table VI. Tuberculosis cases and tuberculosis notification rates by age groups and voivodships. Poland 2018. Rates per 100 000. Data from National TB Register

Tabela VI. Zapadalność na gruźlicę w Polsce w roku 2018 wg grup wieku i województw. Współczynniki na 100000. Dane z Krajowego Rejestru Zachorowań na Gruźlicę

\begin{tabular}{|c|c|c|c|c|c|c|c|c|c|c|c|c|}
\hline \multirow{2}{*}{ Voivodships } & \multicolumn{6}{|c|}{ Numbers } & \multicolumn{6}{|c|}{ Rates per 100000} \\
\hline & Total & $0-14$ & $15-19$ & $20-44$ & $45-64$ & $65+$ & Total & $0-14$ & $15-19$ & $20-44$ & $45-64$ & $65+$ \\
\hline Poland & 5487 & 52 & 60 & 1473 & 2494 & 1408 & 14.3 & 0.9 & 3.3 & 10.5 & 24.7 & 21.3 \\
\hline Dolnośląskie & 377 & 2 & 2 & 112 & 181 & 80 & 13.0 & 0.5 & 1.6 & 10.5 & 23.5 & 15.3 \\
\hline Kujawsko-pomorskie & 211 & 1 & 6 & 80 & 75 & 49 & 10.1 & 0.3 & 5.8 & 10.6 & 13.5 & 14.0 \\
\hline Lubelskie & 497 & 3 & 7 & 118 & 200 & 169 & 23.4 & 1.0 & 6.5 & 15.3 & 35.9 & 45.0 \\
\hline Lubuskie & 119 & 1 & - & 26 & 55 & 37 & 11.7 & 0.6 & - & 7.0 & 20.4 & 22.0 \\
\hline Łódzkie & 406 & 2 & 3 & 96 & 190 & 115 & 16.4 & 0.6 & 2.7 & 11.1 & 28.5 & 24.3 \\
\hline Małopolskie & 440 & 5 & 6 & 92 & 176 & 161 & 13.0 & 0.9 & 3.4 & 7.3 & 20.5 & 29.0 \\
\hline Mazowieckie & 954 & 18 & 7 & 272 & 434 & 223 & 17.7 & 2.1 & 2.8 & 13.8 & 32.0 & 23.8 \\
\hline Opolskie & 127 & - & 1 & 29 & 59 & 38 & 12.9 & - & 2.2 & 8.2 & 21.1 & 21.5 \\
\hline Podkarpackie & 263 & 5 & 5 & 53 & 119 & 81 & 12.4 & 1.6 & 4.4 & 6.6 & 21.6 & 23.6 \\
\hline Podlaskie & 86 & 2 & - & 26 & 34 & 24 & 7.3 & 1.2 & - & 6.0 & 10.6 & 11.9 \\
\hline Pomorskie & 349 & 1 & 3 & 110 & 176 & 59 & 15.0 & 0.3 & 2.6 & 12.8 & 29.8 & 15.7 \\
\hline Śląskie & 844 & 6 & 9 & 241 & 404 & 184 & 18.6 & 0.9 & 4.5 & 15.0 & 32.3 & 22.2 \\
\hline Świętokrzyskie & 209 & - & 2 & 47 & 100 & 60 & 16.8 & - & 3.3 & 10.6 & 29.8 & 25.8 \\
\hline Warmińsko-mazurskie & 124 & 1 & 2 & 26 & 63 & 32 & 8.7 & 0.5 & 2.7 & 4.9 & 16.3 & 14.4 \\
\hline Wielkopolskie & 279 & 4 & 6 & 83 & 135 & 51 & 8.0 & 0.7 & 3.5 & 6.4 & 15.2 & 9.1 \\
\hline Zachodnio-pomorskie & 202 & 1 & 1 & 62 & 93 & 45 & 11.9 & 0.4 & 1.2 & 10.0 & 20.1 & 15.3 \\
\hline
\end{tabular}

Children with tuberculosis represented $0.9 \%$ of the total number of TB cases in Poland (52 pediatric cases including 35 with pulmonary and 17 with extrapulmonary TB). Intrathoracic lymph nodes TB was diagnosed in 7 children.

Tuberculosis was confirmed by culture in 21 (40.4\%) pediatric TB cases; in two children sputum smears were also positive (Tab. IV). In 31 children
Zgłoszono 52 przypadki gruźlicy u dzieci do 14 roku życia, które stanowiły $0,9 \%$ ogółu zachorowań. U dzieci wykryto 35 przypadków gruźlicy płuc i 17 przypadków gruźlicy pozapłucnej. Najczęstszą postacią gruźlicy pozapłucnej u dzieci była gruźlica węzłów chłonnych klatki piersiowej - 7 przypadków. Potwierdzenie bakteriologiczne uzyskano w 21 przypadkach dziecięcych, tzn. w 40,4\% zachorowań w tej grupie wie- 
with negative cultures of specimens, tuberculosis was diagnosed on the basis of the clinical features. In mazowieckie voivodship, having the highest number of cases of tuberculosis in children in Poland, definitive diagnosis of tuberculosis was obtained in 2 out of 18 cases.

The highest incidence rates of tuberculosis in children were recorded in voivodship mazowieckie -2.1 ; podkarpackie -1.6 and podlaskie -1.2 . In 2 voivodships there were no pediatric TB cases (Tab. VII). ku. Wśród przypadków z pewnym rozpoznaniem gruźlicy, potwierdzonych posiewem, było 14 przypadków gruźlicy płuc (40,0\% wszystkich zachorowań na gruźlicę płuc u dzieci) oraz 7 przypadków gruźlicy pozapłucnej, tzn. 41,2\% tej postaci choroby u dzieci. U dwojga dzieci dodatni był także wynik badania bakterioskopowego plwociny. W województwie mazowieckim, gdzie zarejestrowano 18 - najwięcej w Polsce - zachorowań na gruźlicę u dzieci do 14 roku życia, tylko dwa przypadki (gruźlica płuc) zostały potwierdzone bakteriologicznie. W 2018 roku większą niż w roku poprzednim liczbę przypadków pediatrycznych odnotowano w 8 województwach: małopolskim (5 vs. 2); podlaskim (2 vs. 1); lubelskim (3 vs. 2); podkarpackim (5 vs. 4); wielkopolskim (4 vs. 0); lubuskim, warmińsko-mazurskim i zachodniopomorskim (1 vs. 0). W województwie opolskim i świętokrzyskim nie stwierdzono żadnego przypadku gruźlicy u dzieci do lat 14 . W 5 województwach stwierdzono po jednym przypadku gruźlicy dziecięcej; w 3 województwach po dwa przypadki. Największe współczynniki zapadalności na gruźlicę u dzieci stwierdzono w województwach: mazowieckim - 2,1; podkarpackim - 1,6 i podlaskim - 1,2 (Tab. VII).

Table VII. Tuberculosis cases and tuberculosis notification rates in children (0-14 years old) by voivodships. Poland 2014-2018. Rates per 100 000. Data from National TB Register

Tabela VII. Zapadalność na gruźlicę wszystkich postaci wśród dzieci (0-14 lat) w Polsce wg województw w latach 20142018. Współczynniki na 100 000. Dane z Krajowego Rejestru Zachorowań na Gruźlicę

\begin{tabular}{|l|c|c|c|c|c|c|c|c|c|c|}
\hline \multirow{2}{*}{ Voivodships } & \multicolumn{4}{|c|}{ Numbers } & \multicolumn{5}{c|}{ Rates per 100000} \\
\cline { 2 - 12 } & 2014 & 2015 & 2016 & 2017 & 2018 & 2014 & 2015 & 2016 & 2017 & 2018 \\
\hline Poland & 70 & 81 & 103 & 68 & 52 & 1.2 & 1.4 & 1.8 & 1.2 & 0.9 \\
\hline Dolnośląskie & 5 & 2 & 2 & 2 & 2 & 1.2 & 0.5 & 0.5 & 0.5 & 0.5 \\
\hline Kujawsko-pomorskie & 2 & 9 & 6 & 6 & 1 & 0.6 & 2.9 & 1.9 & 1.9 & 0.3 \\
\hline Lubelskie & 2 & 5 & 7 & 2 & 3 & 0.6 & 1.6 & 2.2 & 0.6 & 1.0 \\
\hline Lubuskie & - & - & - & - & 1 & - & - & - & - & 0.6 \\
\hline Lódzkie & 2 & 2 & 2 & 2 & 2 & 0.6 & 0.6 & 0.6 & 0.6 & 0.6 \\
\hline Małopolskie & 4 & 2 & 7 & 2 & 5 & 0.8 & 0.4 & 1.3 & 0.4 & 0.9 \\
\hline Mazowieckie & 28 & 34 & 60 & 27 & 18 & 3.4 & 4.1 & 7.1 & 3.1 & 2.1 \\
\hline Oppolskie & - & - & - & 2 & - & - & - & - & 1.5 & - \\
\hline Podkarpackie & 2 & 1 & 2 & 4 & 5 & 0.6 & 0.3 & 0.6 & 1.2 & 1.6 \\
\hline Podlaskie & 2 & 2 & - & 1 & 2 & 1.2 & 1.2 & - & 0.6 & 1.2 \\
\hline Pomorskie & 1 & 2 & 2 & 5 & 1 & 0.3 & 0.5 & 0.5 & 1.3 & 0.3 \\
\hline Śląskie & 18 & 6 & 8 & 15 & 6 & 2.8 & 0.9 & 1.2 & 2.3 & 0.9 \\
\hline Świętokrzyskie & - & 11 & 2 & - & - & - & 6.3 & 1.2 & - & - \\
\hline Warmińsko-mazurskie & - & 1 & 3 & - & 1 & - & 0.4 & 1.4 & - & 0.5 \\
\hline Wielkopolskie & 4 & 1 & - & - & 4 & 0.7 & 0.2 & - & - & 0.7 \\
\hline Zachodnio - pomorskie & - & 3 & 2 & - & 1 & - & 1.2 & 0.8 & - & 0.4 \\
\hline
\end{tabular}

In 2018, there were 60 cases of tuberculosis among adolescents aged from 15 to 19 years (rate 3.3). 96.7\% of all teenagers with TB had pulmonary TB. In 54 young patients $(90.0 \%$ of all TB cases in teenagers)
W 2018 roku zarejestrowano 60 zachorowań na gruźlicę u młodzieży w wieku od 15 do 19 lat - współczynnik 3,3. Większość młodocianych chorych -96,7\% - miała gruźlicę płuc. Potwierdzenie bakteriologiczne 
the disease was bacteriologically confirmed, mostly in pulmonary TB (52 cases). 36 teenagers with pulmonary TB had positive sputum smears (Tab. III, IV). The highest numbers of teenagers with TB were found in voivodship śląskie - 9; mazowieckie and lubelskie -7 cases per each. The highest incidence rate of tuberculosis in the age group from 15 to 19 years was observed in voivodship lubelskie -6.5 . In the same voivodship the highest incidence of pulmonary TB confirmed by culture and with positive sputum smears was found in this age group (rate 6.5 and 5.6). In two voivodships - lubuskie and podlaskie- there were no TB cases in the age group from 15 to 19 years (Tab. VIII). grú́licy uzyskano u 54 nastolatków, czyli u 90,0\% tej grupy chorych, gruźlicy płuc u 52. U 36 nastoletnich chorych na gruźlicę płuc dodatni był także wynik bakterioskopii plwociny (Tab. III, IV).

Największą liczbę młodocianych chorych na gruźlicę zarejestrowano w woj. śląskim - 9, lubelskim - 7 i mazowieckim - 7. W woj. lubuskim i podlaskim nie zarejestrowano żadnego przypadku gruźlicy w grupie 15-19 lat. Największą zapadalność na gruźlicę u nastolatków - 6,5 - stwierdzono w woj. lubelskim i kujawsko-pomorskim - 5,8 (Tab. VIII). Jednocześnie w województwie lubelskim odnotowano u młodzieży największą zapadalność na gruźlicę płuc potwierdzoną bakteriologicznie $-6,5$. Na taką postać gruźlicy zachorowało w Lubelskiem 7 osób w wieku od 15 do 19 lat. W 4 województwach: lubuskim, podlaskim, świętokrzyskim i zachodnio-pomorskim nie było u nastolatków ani jednego zachorowania na gruźlicę płuc potwierdzoną bakteriologicznie. Największą zapadalność na gruźlicę płuc z dodatnim wynikiem bakterioskopii plwociny u młodzieży stwierdzono w woj. lubelskim - 5,6.

Table VIII. Tuberculosis cases and tuberculosis notification rates in adolescents (15-19 years old) by voivodships. Poland 2014-2018. Rates per 100 000. Data from National TB Register

Tabela VIII. Zapadalność na gruźlicę wszystkich postaci wśród młodzieży (15-19 lat) w Polsce wg województw w latach 2013- 2017. Współczynniki na 100 000. Dane z Krajowego Rejestru Zachorowań na Gruźlicę

\begin{tabular}{|l|c|c|c|c|c|c|c|c|c|c|}
\hline \multirow{2}{*}{\multicolumn{1}{c|}{ Województwa }} & \multicolumn{4}{|c|}{ Numbers } & \multicolumn{5}{c|}{ Rates per 100000} \\
\cline { 2 - 12 } \multicolumn{1}{|c}{ Poland } & 2014 & 2015 & 2016 & 2017 & 2018 & 2014 & 2015 & 2016 & 2017 & 2018 \\
\hline Dolnośląskie & 86 & 83 & 76 & 69 & 60 & 4.1 & 4.1 & 3.9 & 3.6 & 3.3 \\
\hline Kujawsko-pomorskie & 4 & 7 & 5 & 4 & 2 & 2.8 & 5.0 & 3.7 & 3.1 & 1.6 \\
\hline Lubelskie & 2 & 7 & 7 & 6 & 6 & 1.7 & 6.1 & 6.3 & 5.6 & 5.8 \\
\hline Lubuskie & 5 & 3 & 8 & 4 & 7 & 4.0 & 2.5 & 6.9 & 3.6 & 6.5 \\
\hline Lódzkie & - & 4 & - & 3 & - & - & 7.4 & - & 6.0 & - \\
\hline Małopolskie & 11 & 7 & 3 & 10 & 3 & 8.6 & 5.7 & 2.5 & 8.7 & 2.7 \\
\hline Mazowieckie & 2 & 4 & 4 & 3 & 6 & 1.0 & 2.1 & 2.2 & 1.7 & 3.4 \\
\hline Opolskie & 19 & 20 & 28 & 15 & 7 & 7.0 & 7.6 & 10.9 & 5.9 & 2.8 \\
\hline Podkarpackie & 5 & - & 1 & 1 & 1 & 9.5 & - & 2.1 & 2.1 & 2.2 \\
\hline Podlaskie & 4 & 5 & - & 4 & 5 & 3.1 & 4.0 & - & 3.4 & 4.4 \\
\hline Pomorskie & 2 & 1 & - & 2 & - & 2.9 & 1.5 & - & 3.3 & - \\
\hline Śląskie & 2 & 6 & 2 & 1 & 3 & 1.6 & 4.8 & 1.6 & 0.8 & 2.6 \\
\hline Śmiętokrzyskie & 14 & 11 & 10 & 8 & 9 & 6.2 & 5.0 & 4.7 & 3.9 & 4.5 \\
\hline Warmińsko-mazurskie & 3 & 3 & 3 & 2 & 2 & 4.2 & 4.4 & 4.6 & 3.2 & 3.3 \\
\hline Wielkopolskie & 3 & 1 & 2 & 3 & 2 & 3.5 & 1.2 & 2.5 & 4.0 & 2.7 \\
\hline Zachodnio - pomorskie & 3 & - & 2 & 1 & 1 & 3.2 & - & 2.3 & 1.2 & 1.2 \\
\hline
\end{tabular}

In 2018, as in previous years, the male-to-female ratio in all TB cases was $>2$. The proportion of men among all TB cases was $71.1 \%$. There were 3900 cases registered in men - rate 21.0 and 1587 cases in women - rate 8.0 (Tab. IX). The biggest sex differences in incidence rates were observed in age group 55-59
W 2018 roku, podobnie jak w latach poprzednich, zapadalność na gruźlicę wśród mężczyzn była ponad dwukrotnie wyższa niż u kobiet. Zarejestrowano 3900 zachorowań mężczyzn - współczynnik 21,0 i 1587 kobiet - współczynnik 8,0 (Tab. IX). Przypadki gruźlicy u mężczyzn stanowiły $71,1 \%$ ogółu zachorowań. Naj- 
(44.9 vs. 9.8) and in age group 60-64 (43.7 vs. 10.2) (Fig. 1). The lowest incidence rate of tuberculosis in Poland at all was in women in voivodship podlaskie (3.8); the highest - in men in the voivodship lubelskie (35.0) (Tab. IX).

In 2018, 3439 cases of TB lived in cities (rate 14.9) and 2 048- in rural areas (rate 13.4) (Tab. IX). większa różnica zapadalności między mężczyznami a kobietami występowała u osób w wieku od 55 do 59 lat $(44,9$ vs. 9,8$)$ oraz w wieku od 60 do 64 lat $(43,7$ vs. 10,2) (Ryc. 1). Największą zapadalność na gruźlicę wszystkich postaci u mężczyzn stwierdzono w woj. lubelskim - współczynnik 35,0; najmniejszą w woj. podlaskim - współczynnik 10,9; u kobiet największe różnice zapadalności były w tych samych województwach, odpowiednio 12,5 i 3,8 (Tab. IX). Zapadalność na gruźlicę płuc potwierdzoną bakteriologicznie wynosiła u mężczyzn 15,6; u kobiet - 5,2.

W 2018 roku po raz kolejny zapadalność na gruźlicę wśród mieszkańców miast była większa niż na wsi 14,9 vs. 13,4. Zarejestrowano 3439 zachorowań w miastach i $2048 \mathrm{w}$ regionach wiejskich (Tab. IX).

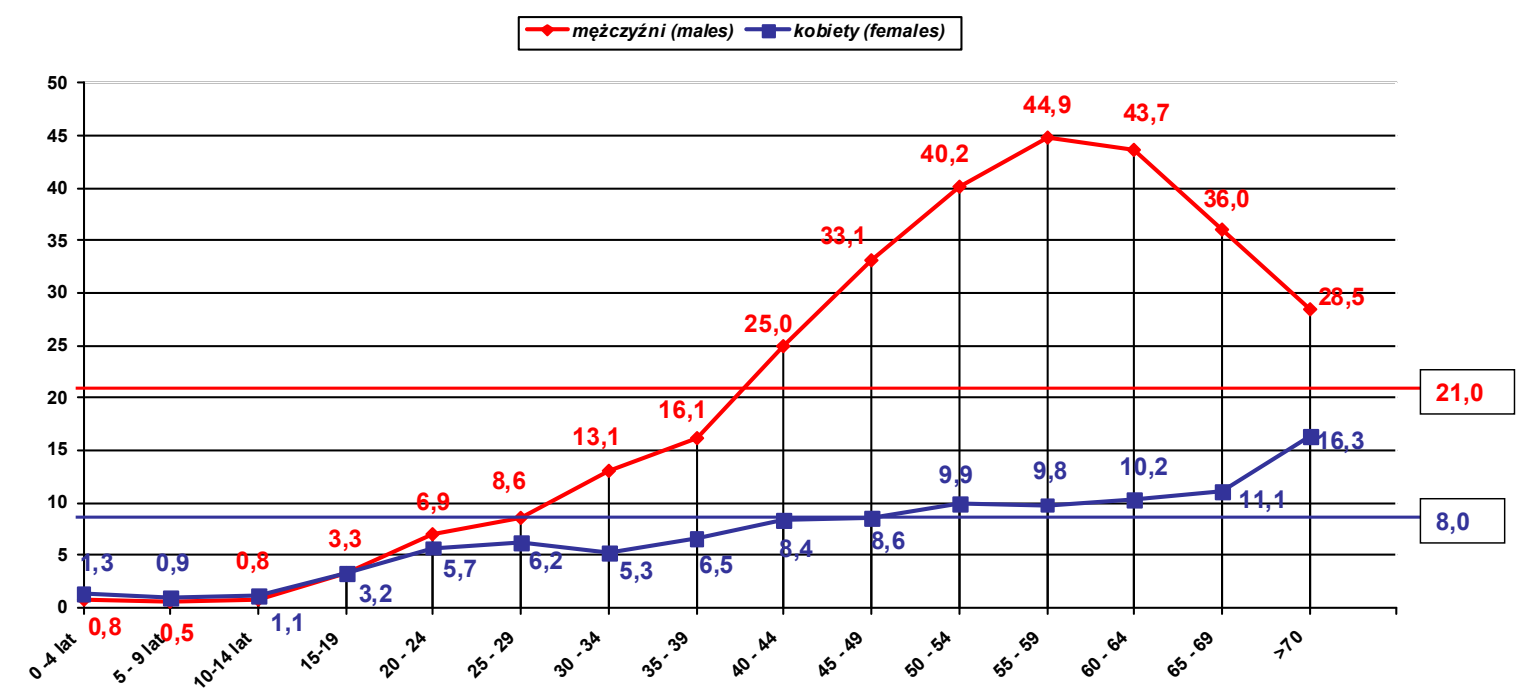

Figure 1. Tuberculosis notification rates by sex and age. Poland in 2018. Rates per 100000 population Rycina 1. Zapadalność na gruźlicę wszystkich postaci wg płci i wieku w Polsce w 2018 roku. Współczynniki na 100000 ludności.

In the past the epidemiological situation of tuberculosis in Poland was worse in rural than in urban areas. In 2018, the $9^{\text {th }}$ time in the history of Register, the incidence of TB in rural areas was lower than in urban population.

Of all 5487 TB cases reported in Poland in 2018, 97 were of foreign origin (1.8\%). In the group of foreign origin TB patients there was one teenager and there were no children. The mean age of cases with foreign citizenship was 35.1 years. The most numerous group were the Ukrainians- 28 persons.

In 2018, according to the data obtained from the National Institute of Public Health - National Institute of Hygiene, in 14 patients with HIV co-infection, tuberculosis was AIDS- indicative disease. In Poland, HIV status of TB patients has not been routinely tested. Data on HIV co-infection in individual TB cases are not reportable.
Wśród chorych na gruźlicę zarejestrowanych w 2018 roku było 97 cudzoziemców, w większości - 80 osób - w wieku od 20 do 44 lat. Przypadki gruźlicy u cudzoziemców stanowiły $1,8 \%$ wszystkich zachorowań. W grupie cudzoziemców był jeden nastolatek, nie odnotowano zachorowań wśród dzieci (0-14). Najwięcej cudzoziemców (38) leczono z powodu gruźlicy na Mazowszu. Największą grupę - 28 osób - stanowili przybysze z Ukrainy; kolejni byli Wietnamczycy ( 9 chorych) i Nepalczycy (8 chorych). Cudzoziemcy, u których rozpoznano gruźlicę, przybyli do Polski z 22 krajów. W 9 przypadkach miejsce pochodzenia nie było znane.

Gruźlica była chorobą wskaźnikową u 14 chorych na HIV/AIDS w 2018 roku. Są to jedyne dane o współwystępowaniu zakażenia HIV i gruźlicy w Polsce.

Wśród chorych na gruźlicę zarejestrowanych w 2018 roku odnotowano 171 osób, które przebywały 
Table IX. Tuberculosis cases and tuberculosis notification rates by sex, place of residence and voivodships. Poland 2018. Rates per 100 000. Data from National TB Register

Tabela IX. Zapadalność na gruźlicę wszystkich postaci w Polsce w roku 2018 wg płci, miejsca zamieszkania i województw. Współczynniki na 100 000. Dane z Krajowego Rejestru Zachorowań na Gruźlicę

\begin{tabular}{|l|c|c|c|c|c|c|c|c|c|c|}
\hline \multirow{2}{*}{\multicolumn{1}{|c|}{ Voivodships }} & \multicolumn{4}{|c|}{ Numbers } & \multicolumn{5}{c|}{ Rates per 100 00 } \\
\cline { 2 - 13 } & Total & Male & Female & $\begin{array}{c}\text { Urban } \\
\text { areas }\end{array}$ & $\begin{array}{c}\text { Rural } \\
\text { areas }\end{array}$ & Total & Male & Female & $\begin{array}{c}\text { Urban } \\
\text { areas }\end{array}$ & $\begin{array}{c}\text { Rural } \\
\text { areas }\end{array}$ \\
\hline Poland & 5487 & 3900 & 1587 & 3439 & 2048 & 14.3 & 21.0 & 8.0 & 14.9 & 13.4 \\
\hline Dolnośląskie & 377 & 281 & 96 & 263 & 114 & 13.0 & 20.1 & 6.4 & 13.2 & 12.6 \\
\hline Kujawsko-pomorskie & 211 & 153 & 58 & 134 & 77 & 10.1 & 15.2 & 5.4 & 10.9 & 9.1 \\
\hline Lubelskie & 497 & 360 & 137 & 199 & 298 & 23.4 & 35.0 & 12.5 & 20.2 & 26.3 \\
\hline Lubuskie & 119 & 81 & 38 & 92 & 27 & 11.7 & 16.4 & 7.3 & 13.9 & 7.6 \\
\hline Lódzkie & 406 & 277 & 129 & 262 & 144 & 16.4 & 23.5 & 10.0 & 16.9 & 15.6 \\
\hline Małopolskie & 440 & 285 & 155 & 200 & 240 & 13.0 & 17.3 & 8.9 & 12.2 & 13.7 \\
\hline Mazowieckie & 954 & 659 & 295 & 628 & 326 & 17.7 & 25.5 & 10.5 & 18.1 & 17.0 \\
\hline Opolskie & 127 & 94 & 33 & 83 & 44 & 12.9 & 19.7 & 6.5 & 15.7 & 9.5 \\
\hline Podkarpackie & 263 & 188 & 75 & 105 & 158 & 12.4 & 18.0 & 6.9 & 12.0 & 12.6 \\
\hline Podlaskie & 86 & 63 & 23 & 47 & 39 & 7.3 & 10.9 & 3.8 & 6.5 & 8.4 \\
\hline Pomorskie & 349 & 279 & 70 & 243 & 106 & 15.0 & 24.6 & 5.9 & 16.4 & 12.6 \\
\hline Śląsie & 844 & 625 & 219 & 699 & 145 & 18.6 & 28.6 & 9.3 & 20.0 & 13.8 \\
\hline Świętokrzyskie & 209 & 135 & 74 & 98 & 111 & 16.8 & 22.2 & 11.6 & 17.5 & 16.2 \\
\hline Warmińsko-mazurskie & 124 & 86 & 38 & 61 & 63 & 8.7 & 12.3 & 5.2 & 7.2 & 10.7 \\
\hline Wielkopolskie & 279 & 192 & 87 & 174 & 105 & 8.0 & 11.3 & 4.9 & 9.2 & 6.6 \\
\hline Zachodnio-pomorskie & 202 & 142 & 60 & 151 & 51 & 11.9 & 17.1 & 6.9 & 12.9 & 9.5 \\
\hline
\end{tabular}

Tuberculosis was diagnosed in 171 individuals in prisons (incidence rate amounted to 230.8 per 100000 inmates).

Data on the mortality from tuberculosis were extracted from death certificates by the Central Statistical Office. Tuberculosis was considered the underlying cause of death in 490 of the deceased in 2017 , corresponding to a death rate of 1.3 per 100 000 population. This rate was lower than in previous years (Tab. X). 468 subjects died because pulmonary tuberculosis. In 2017, deaths from tuberculosis represented $0.1 \%$ of all deaths and $25.4 \%$ of deaths due to infectious and parasitic diseases in Poland.

The highest TB mortality rate (3.1) was in the age group of 65 years and more. People aged 45- 64 were the largest group among those who died of tuberculosis (223 persons; rate 2.2). In 2017, there were no deaths from this cause in children and adolescents. Number of deaths attributed to tuberculosis was more than 3.6 times higher in men - 383 deaths - than in women 107 deaths; rates respectively -2.1 and 0.6. Similar differences were observed also in the previous years.

The highest death rates from tuberculosis were in voivodships śląskie and podlaskie (1.9), the lowest - in voivodship wielkopolskie (0.7). In 2017, the highest TB mortality rate in Poland was in men in voivodships śląskie and podlaskie (3.3); the lowest w aresztach śledczych i zakładach karnych (zapadalność 230,8 na 100000 osadzonych).

W 2017 roku gruźlica była przyczyną zgonu 490 osób. Współczynnik umieralności wynosił 1,3 na 100000 ludności, mniej niż kiedykolwiek w przeszłości (Tab. X). Główną przyczyną zgonów z powodu gruźlicy, podobnie jak w latach wcześniejszych, była gruźlica płuc - zmarło na nią 468 chorych - współczynnik 1,2.

$\mathrm{Z}$ powodu gruźlicy pozapłucnej zmarło 22 chorych. Zgony z powodu gruźlicy stanowiły $0,1 \%$ ogółu zgonów w 2017 roku w Polsce i 25,4\% zgonów z powodu wszystkich chorób zakaźnych i pasożytniczych.

Najwięcej osób zmarłych z powodu gruźlicy było w wieku od 45 do 64 lat (223; współczynnik 2,2. Największy współczynnik umieralności z powodu gruźlicy stwierdzono $w$ grupie wieku $\geq 65$ lat $-3,1$. Na gruźlicę zmarło 197 osób w takim wieku, którzy stanowili 40,2\% ogółu zmarłych na gruźlicę. Nie było żadnego zgonu na grú́licę u dzieci i u młodzieży. W pięcioleciu 2013-2017 zarejestrowano jeden przypadek zgonu z powodu gruźlicy u dzieci (2016 rok); wśród nastolatków po jednym przypadku zgonu z tej przyczyny stwierdzono w 2013 i, dotychczas po raz ostatni, w 2014 roku.

W 2017 roku liczba mężczyzn zmarłych z powodu gruźlicy - 383 - była 3,6 razy większa niż kobiet - 107; umieralność odpowiednio - 2,1 i 0,5. Ponad trzykrotnie wyższe liczby mężczyzn niż kobiet zmarłych z powodu 
$(0.2)$ - in women in voivodships wielkopolskie and zachodnio-pomorskie (Tab. X) $(4,5)$. gruźlicy stwierdzano także we wcześniejszych latach (Tab. X).

Największe w kraju współczynniki umieralności z powodu gruźlicy były w woj. śląskim i podlaskim 1,9 (87 i 23 zgony) oraz dolnośląskim - 1,7 (49 zgonów), zaś najniższe w woj. wielkopolskim - $0,7(0,5)$ oraz opolskim, podkarpackim i pomorskim - 0,9.

Przy uwzględnieniu płci największą w Polsce umieralność z powodu gruźlicy stwierdzono w 2017 roku u mężczyzn w woj. podlaskim i śląskim - 3,3; najmniejszą- u kobiet w woj. wielkopolskim oraz zachodnio-pomorskim - 0,2 (3 i 2 zgony) (Tab. X) (4,5).

Table X. Mortality from tuberculosis (all forms) by sex, place of residence and voivodships. Poland 2017. Rates per 100000 population. Data from Central Statistical Office

Tabela X. Umieralność z powodu gruźlicy w Polsce wg płci, miejsca zamieszkania i województw w 2017 roku. Współczynniki na 100000 ludności. Dane z Głównego Urzędu Statystycznego

\begin{tabular}{|l|c|c|c|c|c|c|c|c|c|c|}
\hline \multirow{2}{*}{ Voivodships } & \multicolumn{2}{|c}{ Total } & \multicolumn{2}{c}{ Male } & \multicolumn{2}{c|}{ Female } & \multicolumn{2}{c|}{ Urban areas } & \multicolumn{2}{c|}{ Rural areas } \\
\cline { 2 - 14 } & Number & Rate & Number & Rate & Number & Rate & Number & Rate & Number & Rate \\
\hline O G Ó Ł E M & 490 & 1.3 & 383 & 2.1 & 107 & 0.5 & 304 & 1.3 & 186 & 1.2 \\
\hline 1. Dolnośląskie & 49 & 1.7 & 40 & 2.9 & 9 & 0.6 & 36 & 1.8 & 13 & 1.4 \\
\hline 2. Kujaw.-pomorskie & 20 & 1.0 & 12 & 1.2 & 8 & 0.7 & 12 & 1.0 & 8 & 0.9 \\
\hline 3. Lubelskie & 32 & 1.5 & 23 & 2.2 & 9 & 0.8 & 9 & 0.9 & 23 & 2.0 \\
\hline 4. Lubuskie & 14 & 1.4 & 10 & 2.0 & 4 & 0.8 & 11 & 1.7 & 3 & 0.8 \\
\hline 5. Łódzkie & 28 & 1.1 & 22 & 1.9 & 6 & 0.5 & 19 & 1.2 & 9 & 1.0 \\
\hline 6. Małopolskie & 35 & 1.0 & 24 & 1.5 & 11 & 0.6 & 16 & 1.0 & 19 & 1.1 \\
\hline 7. Mazowieckie & 71 & 1.3 & 55 & 2.1 & 16 & 0.6 & 45 & 1.3 & 26 & 1.4 \\
\hline 8. Opolskie & 9 & 0.9 & 7 & 1.5 & 2 & 0.4 & 3 & 0.6 & 6 & 1.3 \\
\hline 9. Podkarpackie & 20 & 0.9 & 14 & 1.3 & 6 & 0.6 & 2 & 0.2 & 18 & 1.4 \\
\hline 10. Podlaskie & 23 & 1.9 & 19 & 3.3 & 4 & 0.7 & 16 & 2.2 & 7 & 1.5 \\
\hline 11. Pomorskie & 22 & 0.9 & 18 & 1.6 & 4 & 0.3 & 9 & 0.6 & 13 & 1.6 \\
\hline 12. Śląskie & 87 & 1.9 & 72 & 3.3 & 15 & 0.6 & 78 & 2.2 & 9 & 0.9 \\
\hline 13. Ś Siętokrzyskie & 18 & 1.4 & 15 & 2.5 & 3 & 0.5 & 5 & 0.9 & 13 & 1.9 \\
\hline 14. Warm.-mazurskie & 15 & 1.0 & 10 & 1.4 & 5 & 0.7 & 6 & 0.7 & 9 & 1.5 \\
\hline 15. Wielkopolskie & 26 & 0.7 & 23 & 1.4 & 3 & 0.2 & 20 & 1.0 & 6 & 0.4 \\
\hline 16. Zach.-pomorskie & 21 & 1.2 & 19 & 2.3 & 2 & 0.2 & 17 & 1.5 & 4 & 0.7 \\
\hline
\end{tabular}

\section{DISCUSSION}

In 2018, the total of 52862 cases of tuberculosis were registered in $30 \mathrm{EU} / \mathrm{EEA}$ countries (Latvia did not provide any case-based data). The incidence rate of tuberculosis in 100000 of all inhabitants was 10.2 (estimated worldwide incidence - 132.0; in Poland - 14.3). The overall notification rate and the rates in most countries have been decreasing over the last five years. The epidemiological situation of tuberculosis differs significantly between EU/EEA countries. In Iceland the incidence rate was 2.3 (eight patients) and in Romania 62.5 per 100 000. In 23 EU/EEA countries the incidence rates were less than 10 per 100000 .

\section{DYSKUSJA}

W 2018 roku w 30 krajach UE/EOG (Lotwa nie podała danych) zarejestrowano łącznie 52862 przypadki gruźlicy. Współczynnik zapadalności na gruźlicę obliczony na 100000 wszystkich mieszkańców wyniósł 10,2 (szacunkowa zapadalność na świecie - 132,0; w Polsce - 14,3). Od 2002 roku obserwuje się w krajach UE/EOG stały spadek zapadalności na gruźlicę. Sytuacja epidemiologiczna gruźlicy różni się znacząco w poszczególnych krajach UE/EOG. W Islandii współczynnik zapadalności wynosił 2,3 (ośmiu chorych) a w Rumunii- 62,5 na 100 000. W 23 krajach UE/EOG współczynniki zapadalności były mniejsze niż 10 na 100000. 
The countries with the lowest incidence rates were, apart from Iceland, Liechtenstein with 2.6 (one patient); Greece with 4.0; Finland and the Czech Republic with 4.2; Sweden with 4.9. Two EU countries (Romania and Portugal) had incidence rates above 20 per 100 000. Five countries - France, Germany, Poland, Romania and the United Kingdom - reported $63 \%$ of all TB patients in the EU/EEA. Patients in Romania accounted for $23.0 \%$ of all TB cases in EU/EEA countries (12 205).

In 2018, 34.5\% of all TB cases in the EU/EEA (18 246 patients) were born in a country other than the country notifying the disease. Of the total number of foreign origin $\mathrm{TB}$ patients registered in the EU/ EEA, $57.7 \%$ were reported as being from Germany, France and the UK. The group of countries with the highest percentage of immigrants among TB patients $(>85 \%)$ included Malta, Cyprus, Liechtenstein, Iceland, Sweden and Norway. The percentage of foreign origin TB cases was the lowest in Romania and Bulgaria $(<1 \%)$. The only tuberculosis patient reported by Liechtenstein was a foreigner.

In theEU/EEA countries, new cases of tuberculosis, which had not been previously treated, accounted for $76.9 \%$ of all cases. In 7 countries, including Poland, the percentage of patients previously treated exceeded $10 \%$. In Poland, the percentage of patients with bacteriologically confirmed tuberculosis was higher than the EU/EEA average ( $74.3 \%$ vs. $68.2 \%$ ). The highest percentage of definitive cases of tuberculosis was found in Liechtenstein $(100 \%$, i.e. the only patient from this country), the lowest- in Iceland (25.0\%).

In Poland, from the 1970s to 2014, tuberculosis incidence rates were the higher the older the age group to which they referred. In 2018, the highest incidence rate was found not in the $\geq 65$ age group but in people aged 45 to 64 . Patients of this age constituted the highest percentage of all patients (45.5\%). The highest incidence rate in patients aged 45-64 years was also found in bacteriologically confirmed lung tuberculosis and in bacteriologically confirmed patients with positive sputum bacterioscopy. The highest incidence rate in the EU/EEA countries was found in the age group from 25 to 44 years - rate 12.5. Persons $>64$ years of age constituted less than $20 \%$ of cases. The highest percentage of elderly people among TB patients was in Croatia, Iceland, Slovenia ( $>1 / 3$ of all cases). The age structure of TB patients in EU/EEA countries is probably influenced by high participation of immigrants, who are usually younger people. Also in Poland, the average age of immigrants with tuberculosis in 2018 was lower than that of patients originating from the natives (35.1 vs. 54.2 years).
Do krajów o najmniejszej zapadalności należy, oprócz Islandii, Księstwo Lichtensteinu - 2,6 (jeden chory); Grecja - 4,0; Finlandia i Czechy - 4,2; Szwecja - 4,9. Dwa kraje UE (Rumunia i Portugalia) miały współczynniki zapadalności większe niż 20 na 100 000. Pięć krajów - Francja, Niemcy, Polska, Rumunia i Wielka Brytania zgłosiły $63 \%$ wszystkich chorych na gruźlicę w UE/EOG. Chorzy zarejestrowani w Rumunii stanowili 23,0\% wszystkich przypadków gruźlicy w krajach UE/EOG (12 205).

W 2018 roku 34,5\% wszystkich przypadków gruźlicy w UE/EOG (18 246 chorych) stanowiły osoby urodzone w innym kraju niż kraj zgłaszający zachorowanie lub bez obywatelstwa tego kraju. Niemcy Francja i Wielka Brytania zgłosiły łącznie 57,7\% z ogólnej liczby cudzoziemców chorych na gruźlicę zarejestrowanych w UE/EOG. Do grupy krajów o największym odsetku imigrantów wśród chorych na gruźlicę ( $>85 \%)$ należały Malta, Cypr, Księstwo Lichtensteinu, Islandia, Szwecja i Norwegia. Odsetek cudzoziemców wśród chorych na gruźlicę był najmniejszy w Rumunii i Bułgarii $(<1 \%)$. Jedyny chory na gruźlicę zgłoszony przez Księstwo Lichtensteinu był cudzoziemcem.

W krajach UE/EOG nowe przypadki gruźlicy, o których wiadomo było, że nie były wcześniej leczone, stanowiły $76,9 \%$ wszystkich zachorowań. W 7 krajach, w tym w Polsce, odsetek chorych poprzednio leczonych przekraczał 10\%. W Polsce odsetek chorych na gruźlicę potwierdzoną bakteriologicznie był większy niż średni w krajach UE/EOG (74,3\% vs. 68,2\%). Największy odsetek pewnych przypadków gruźlicy stwierdzono w Księstwie Lichtensteinu (100\% czyli jedyny chory $\mathrm{z}$ tego kraju), najniższy- w Islandii (25,0\%).

W Polsce od lat siedemdziesiątych XX wieku do 2014 roku współczynniki zapadalności na gruźlicę były tym większe, im starsza była grupa wieku, do której się odnosiły. Później, także w 2018 roku, największą zapadalność stwierdzano nie u osób najstarszych, w wie$\mathrm{ku} \geq 65$ lat ale u 45- 64 letnich. Była to najliczniejsza grupa chorych- 45,5\%. Największą zapadalność u osób w wieku od 45 do 64 lat stwierdzano także w odniesieniu do gruźlicy płuc potwierdzonej bakteriologicznie oraz do potwierdzonej bakteriologicznie z dodatnimi wynikami bakterioskopii plwociny. W krajach UE/ EOG największą zapadalność stwierdzono w grupie wieku od 25 do 44 lat - współczynnik 12,5. Osoby > 64 lat stanowiły mniej niż $20 \%$ przypadków. Największy odsetek osób w wieku podeszłym wśród chorych na gruźlicę był w Chorwacji, Islandii, Słowenii (> 1/3 wszystkich przypadków). Na strukturę wieku chorych na gruźlicę w krajach UE/EOG wpływa zapewne imigracja - imigranci są zwykle młodymi osobami. Także w Polsce średnia wieku imigrantów chorych na gruźlicę była w 2018 roku mniejsza niż chorych wywodzących się ze społeczności autochtonicznej (35,1 vs. 54,2 roku). 
In 2018 , as in previous years, the percentage of cases of extrapulmonary tuberculosis $(4.4 \%$ of the total number of cases) was small in Poland; in the EU/EEA it was $22.4 \%$. The highest percentage of extrapulmonary TB patients was found in the Netherlands (42.2\%), Great Britain (41.8\%), and Norway $(39.7 \%)$; the lowest in Hungary $(3.0 \%)$ and in Liechtenstein, where only one case of tuberculosis was found and it was pulmonary TB.

In Poland, the percentage of children with tuberculosis has been small for years $(0.9 \%$ of the total number of patients in 2018). In the EU/EEA countries, the percentage of children among all TB patients with a known age was $4.0 \%$; the incidence rate in the pediatric group (2.5) was higher than in Poland (0.9). The highest incidence rate of tuberculosis in children was recorded in Romania - 17.8 per 100000.

In the EU/EEA there is a predominance of men among TB patients (2.0:1; in Greece 3.1:1), the highest, as in Poland, in older age groups. In Cyprus, Iceland and Norway, the number of women with tuberculosis was higher than men.

In 2018, HIV test results were known in 23783 $(45.0 \%)$ cases in EU/EEA. HIV infection status in the TB cases was reported, with different completeness of data, by 21 countries. Nine countries, including Poland, do not report on HIV status in the notified cases. HIV co-infection was identified in 4.2\% (991) of people with a known test result. The percentage of TB patients co-infected with HIV in EU/EEA countries has been gradually decreasing in recent years. In Poland the number of people infected with $\mathrm{HIV}$, in whom tuberculosis was an AIDS-defining disease, has been small for years.

MDR-TB was diagnosed in 999 people in the EU/ EEA countries, i.e. $3.7 \%$ of patients from the group 26881 with known drug susceptibility results $(1.3 \%$ in Poland). The percentage of MDR-TB cases was higher among patients with relapse than in those treated for the first time (13.1\% vs. $2.3 \%)$. Most MDR-TB cases were detected in Romania (354), Lithuania (170) and Germany (98). No cases of MDR-TB were found in five EU countries (Cyprus, Iceland, Liechtenstein, Malta, Slovenia). Poland is among ten countries (including those without MDRTB) where the percentage of MDR-TB is lower than the rest. In Estonia and Lithuania, i.e. the countries with the highest prevalence of MDR-TB, this form of TB represented $24.6 \%$ and $17.1 \%$ of cases. Latvia, which has so far been one of the countries with high MDR-TB prevalence, did not provide data. The proportion of MDR-TB patients among total TB patients in EU/EEA countries has decreased over the last decade from $4.6 \%$ in 2009 to $3.6 \%$ in 2018 . In 2018, 808 patients with MDR-TB had a second line
W 2018 roku, podobnie jak w latach ubiegłych, odsetek przypadków gruźlicy pozapłucnej $(4,4 \%$ ogółu zachorowań) był w Polsce mały; w UE/EOG wynosił $22,4 \%$. Największy odsetek chorych na gruźlicę pozapłucną stwierdzono w Holandii $(42,2 \%)$, Wielkiej Brytanii (41,8\%), i Norwegii (39,7\%); najniższy na Węgrzech $(3,0 \%)$ i w Księstwie Lichtensteinu, gdzie stwierdzono tylko jedno zachorowanie na gruźlicę i była to gruźlica płuc.

W Polsce odsetek dzieci chorych na gruźlicę jest od lat mały $(0,9 \%$ ogółu chorych w 2018 roku), co można tłumaczyć małą aktualnie transmisją zakażenia prątkiem gruźlicy w społeczeństwie, a także niewielkim napływem do Polski rodzin z dziećmi z krajów o złej sytuacji epidemiologicznej gruźlicy. W krajach UE/ EOG odsetek dzieci wśród ogółu chorych na gruźlicę ze znanym wiekiem wynosił 4,0\%; współczynnik zapadalności w grupie pediatrycznej $(2,5)$ był wyższy niż w Polsce $(0,9)$. Największy wskaźnik zapadalności na gruźlicę u dzieci odnotowano w Rumunii - 17,8 na 100000.

W UE/EOG stwierdza się przewagę mężczyzn wśród chorych na gruźlicę (2,0:1) (w Grecji 3,1:1), największą, podobnie jak w Polsce, w starszych grupach wieku. Na Cyprze, w Islandii i Norwegii liczba kobiet chorych na gruźlicę była większa niż mężczyzn.

W 2018 roku wynik testu na obecność zakażenia HIV był znany w 23783 (45,0\%) przypadkach gruźlicy w UE/EOG. Dane, często niekompletne, pochodziły z 21 krajów. W dziewięciu krajach, w tym w Polsce, nie wykonuje się rutynowo badania na obecność zakażenia HIV u chorych na gruźlicę lub nie udostępnia wyniku. Zakażenie HIV wykryto u 4,2\% (991) osób ze znanym wynikiem testu. Odsetek chorych na gruźlicę zakażonych HIV w krajach UE/EOG zmniejsza się stopniowo w ostatnich latach. W Polsce liczba osób zakażonych HIV, u których gruźlica była chorobą wskaźnikową dla AIDS, jest od lat mała.

MDR-TB rozpoznano u 999 osób w krajach UE/ EOG tzn. u 3,7\% chorych z grupy

26881 ze znanymi wynikami lekowrażliwości (w Polsce 1,3\%). Odsetek przypadków MDR-TB był większy wśród chorych ze wznową choroby niż u osób leczonych po raz pierwszy (13,1\% vs. 2,3\%). Najwięcej takich przypadków wykryto w Rumunii (354), na Litwie (170) i w Niemczech (98). W pięciu krajach unijnych nie stwierdzono żadnego przypadku MDR-TB (Cypr, Islandia, Księstwo Lichtensteinu, Malta, Słowenia). Polska jest w dziesiątce krajów (wliczając kraje bez MDR-TB), gdzie odsetek MDR-TB jest niższy niż w pozostałych. W Estonii i na Litwie, tzn. w krajach o największym rozpowszechnieniu MDR-TB, ta postać gruźlicy stanowiła 24,6\% i 17,1\% przypadków gruźlicy. Łotwa, która należała dotychczas do krajów o dużym rozpowszechnieniu MDR-TB, nie podała danych. 
antimicrobial susceptibility tests. $19.6 \%$ of them were found to have XDR-TB. The results of MDRTB treatment has been invariably poor. Treatment success was achieved in $49.9 \%$ of patients treated for this form of TB in EU/EEA countries, $15.7 \%$ of these patients died during treatment. These data concerned 1182 patients with MDR-TB registered in 2016. In Poland, for legal reasons, the results of treatment of tuberculosis patients are not collected and cannot be reported to the ECDC.

Data on tuberculosis in prison were provided by 15 EU/EEA countries in 2018. The relative risk of tuberculosis in inmates is almost 15 times higher than in the general population of these countries $(2,4)$.

\section{CONCLUSIONS}

In 2018, the incidence rate of tuberculosis in Poland was still higher than overall incidence in the EU/EEA countries. In 2018, as in previous years, significant regional differences in the incidence of TB were observed in Poland (from 7.3 to 23.4 per 100 000). In two Polish voivodships the incidence rates were below EU/EEA average.

In Poland, what was not common in whole Europe, the highest TB incidence rate was in older subjects (aged 45-64 years). Children under 15 years accounted for $0.9 \%$ of all TB cases, corresponding to the incidence of 0.9 per 100000 .

In Poland, men dominated among TB patients to a greater extent than in most EU and EEA countries. For every female case of TB in Poland, 2.5 male cases were reported (in EU and EEA countries this proportion was one to two). The biggest differences in the TB incidence rates between the two sex groups, over four times, occurred in persons aged 5564 years.

Thirty-five per cent of all TB cases in the EU/ EEA were of foreign origin; in Poland participation of foreign-origin (non-citizen) TB cases among TB patients was one of the smallest in the region $(1.8 \%)$. In Poland, TB was AIDS-defining disease in 14 persons with HIV co-infection. That's all that is known in this regard, because HIV status is not routinely tested in TB patients in the country. In Poland, MDR-TB was less prevalent than in the EU/ EEA countries $(1.3 \%$ vs $3.7 \%$ of cases with relevant DST results). The participation of persons with a nonPolish citizenship among patients with MDR-TB was bigger than among overall TB patients. Tuberculosis mortality has been gradually decreasing in Poland over the years but is still higher than the EU/EEA average.
Udział chorych na MDR-TB wśród ogółu chorych na gruźlicę w krajach UE/EOG zmniejszył się w ostatnim dziesięcioleciu od 4,6\% w roku 2009 do 3,6\% w 2018 roku. W 2018 roku 808 chorych na MDR-TB miało badanie lekowrażliwości na leki przeciwprątkowe drugiej linii- u 19,6\% badanych wykryto XDR-TB.

Wyniki leczenia MDR-TB są złe; sukces leczenia uzyskano u 49,9\% chorych leczonych na taką postać gruźlicy w krajach UE/EOG; 15,7\% tych chorych zmarło w czasie leczenia. Dane dotyczą 1182 chorych na MDR-TB zarejestrowanych w 2016 roku.

Dane o gruźlicy u więźniów dostarczyło w 2018 roku 15 krajów UE/EOG, w tym Polska. Względne ryzyko gruźlicy u osób osadzonych w zakładach karnych jest blisko 15 razy większe niż w ogólnej populacji tych krajów. Umieralność z powodu gruźlicy w całej UE/EOG wynosiła 0,7 na 100000 populacji, mniej niż w Polsce1,3 (>4 na 100000 na Litwie i w Rumunii)(2,4).

\section{PODSUMOWANIE I WNIOSKI}

W 2018 roku liczba chorych i zapadalność na gruźlicę w Polsce były mniejsze niż w 2017 roku. Był to kolejny rok potwierdzający spadkowy trend zapadalności na gruźlicę w kraju.

Utrzymywały się znaczne różnice współczynników zapadalności w poszczególnych województwach - od 7,3 w Podlaskiem do 23,4 w woj. lubelskim. W czterech województwach- podlaskim $(7,3)$, wielkopolskim $(8,0)$, warmińsko-mazurskim $(8,7)$ i kujawsko-pomorskim $(10,1)$ współczynniki zapadalności były mniejsze niż średnie w krajach UE/EOG $(10,2)$.

W Polsce wśród chorych na gruźlicę dominowali mężczyźni, w stopniu większym, niż w przeważającej liczbie krajów UE i EOG. W Polsce, co nie jest w Europie zjawiskiem typowym, największe współczynniki zapadalności stwierdza się od lat u starszych osób, choć już nie w najstarszej grupie wieku $\geq 65$ lat, jak było do roku 2014. Zapadalność na gruźlicę nastolatków w Polsce jest większa niż dzieci. 69,2\% nastoletnich chorych na gruźlicę płuc z dodatnimi posiewami plwociny miało także dodatni wynik bakterioskopii plwociny. Przypadki tej wysoce zakaźnej postaci gruźlicy u nastolatków grożą transmisją zakażenia do wielu osób w związku z mobilnością młodzieży w społeczności i jej bliskim kontaktom w grupach rówieśniczych. Fakt ten podkreśla znaczenie badań przesiewowych osób z kontaktu $z$ chorymi na gruźlicę, szybkie wykrywanie przypadków aktywnej choroby i leczenie profilaktyczne osób zakażonych prątkiem gruźlicy.

W Polsce odsetki przypadków MDR-TB były niższe niż przeciętne w krajach UE i EOG. Mała liczba osób, u których gruźlica była chorobą definiująca AIDS wskazywać może, że współwystępowanie gruźlicy i HIV jest w naszym kraju rzadkie. Nie wykonuje się 


\section{REFERENCES}

1. Global tuberculosis report 2019. Geneva: World Health Organization; 2019.

2. European Centre for Disease Prevention and Control/WHO Regional Office for Europe. Tuberculosis surveillance in Europe 2020 - 2018 data. Stockholm: ECDC; 2020.

3. Ustawa z dnia 5 grudnia 2008 r. o zapobieganiu oraz zwalczaniu zakażeń i chorób zakaźnych u ludzi. (Dz.U. z 2019 r. poz. 1239 z uwzględnieniem zmian wprowadzonych).

4. National Tuberculosis Register, National Tuberculosis and Lung Diseases Research Institute, Warsaw.

5. Korzeniewska-Koseła M.: Tuberculosis In Poland In 2017. Przegl Epidemiol 2019;73(20) 211-226.

Received: 27.04.2020

Accepted for publication: 12.05 .2020

Otrzymano: 27.04.2020 r.

Zaakceptowano do publikacji: $12.05 .2020 \mathrm{r}$. jednak powszechnie badań wykrywających zakażenie HIV u chorych na gruźlicę.

W porównaniu $\mathrm{z}$ wieloma krajami UE i EOG procent imigrantów w zbiorowości chorych na gruźlicę był w Polsce mały (większy w grupie chorych na MDR-TB).

Współczynnik umieralności $\mathrm{z}$ powodu gruźlicy w 2017 roku był mniejszy niż we wcześniejszych latach ale nadal wyższy niż średni w krajach UE/EOG.

\section{Address for correspondence:}

Adres do korespondencji:

Prof. nadzw. dr hab. Maria Korzeniewska-Koseła

National Tuberculosis and Lung Diseases Research Institute,

Department of Tuberculosis Epidemiology and Surveillance

26 Płocka Street, 01-138 Warsaw, Poland

Tel. +48224312123

e-mail: m.korzeniewska@igichp.edu.pl 